\title{
Coronary heart disease in the Medical Research Council trial of treatment of mild hypertension
}

\author{
MEDICAL RESEARCH COUNCIL WORKING PARTY ON MILD HYPERTENSION
}

SUMMARY Seventeen thousand three hundred and fifty four mildly hypertensive people with diastolic blood pressures between 90 and $109 \mathrm{~mm} \mathrm{Hg}$ at screening were randomised to active treatment, with bendrofluazide or propranolol, or to placebo tablets. They were followed for a is maximum of five and a half years, giving a total of 85572 patient-years of observation. There were $\dot{\omega}$ 456 myocardial infarctions or sudden coronary deaths. Drug treatment did not affect the overall $\dot{\omega}$ rate of coronary events. Rates per thousand person-years were 8.3 and 9.0 in men and 1.8 and 1.7 in + women in the active treatment and placebo groups respectively. Event rates were much higher in smokers than in non-smokers on placebo treatment $(12.6$ and 7.5 in men and 3.5 and 1.0 in women in smokers and non-smokers respectively). An analysis of subgroup results showed a lower event rate in non-smoking men on propranolol than in non-smokers on placebo $(5.0$ and 7.5 per thousand $\stackrel{\rho}{工}$ person-years respectively). Bendrofluazide had no apparent effect on the event rate. The $\vec{\varphi}$ interaction between the type of treatment (propranolol, bendrofluazide, or placebo) and smoking in $\infty$ determining the coronary event rate was not statistically significant, however. The incidence of 0 electrocardiographic changes of silent infarction-that is major Q/QS abnormalities-differed little with sex, smoking habit, or treatment with either active drug.

One of the main aims of the Medical Research Council's trial of the efficacy of antihypertensive treatment of patients with mild hypertension was to determine whether such treatment, with either a thiazide diuretic or a $\beta$ blocker, would be associated with a change in the incidence of coronary events. ${ }^{1}$

While the Medical Research Council study was in progress the results of both the Hypertension Detection and Follow-up Program ${ }^{2}$ (HDFP) and the Australian National Blood Pressure Study ${ }^{3}$ (ANBPS) appeared. Both these trials showed some reduction in fatal myocardial infarctions in treated groups, although extrapolation from the results of the Hypertension Detection and Follow-up Program was difficult because the study did not include an untreated control group and generalisation from the Australian National Blood Pressure Study was of limited value because rather few coronary events

Requests for reprints to Mr P J Brennan, MRC Epidemiology and Medical Care Unit, Northwick Park Hospital, Watford Road, Harrow, Middlesex HA1 3UJ.

Accepted for publication 19 August 1987 occurred in that trial. Another report, from the Multiple Risk Factor Intervention Trial (MRFIT) suggested that thiazide treatment of people with $\underset{\odot}{\vec{D}}$ abnormal electrocardiograms might increase deaths from coronary heart disease. ${ }^{4}$ Overall, the picture $\frac{0}{\sigma}$ remained unclear and it was postulated that adverse 3 . metabolic effects of commonly used antihypertensive $\delta$ drugs might counteract any beneficial effects of pressure lowering on coronary heart disease. ${ }^{5}$

The Medical Research Council trial data suggested a further complexity, in that retrospective subgroup analysis indicated that propranolol might perhaps protect against coronary events, though in $\mathrm{N}$ non-smokers only. ${ }^{1}$ This tentative suggestion $\tilde{O}$ received some support from the independent finding $N$ in the International Prospective Primary Prevention ${ }^{\circ}$ Study in Hypertension (IPPPSH) that the rate of cardiac events was lower in non-smoking men ran- $\frac{\mathscr{D}}{\mathscr{}}$ domised to antihypertensive treatment, including $\stackrel{?}{-}$ oxprenolol, than in those whose antihypertensive 0 regimen did not include a $\beta$ blocker. ${ }^{6}$

\section{Patients and methods}

These have been described elsewhere ${ }^{1}$ and only the 
essential details are given here.

The 17354 participants were men or women aged 35-64 years at entry, with sustained diastolic (V) pressures 90-109 $\mathrm{mm} \mathrm{Hg}$ over the screening period. People with a history of definite myocardial infarction within the previous three months, angina, signs of cardiac failure, or electrocardiographic evidence of a silent myocardial infarction or of left bundle branch block were ineligible. Patients were randomly allocated at entry to groups taking either bendrofluazide $(n=4297)$ or propranolol $(n=4403)$ or placebo tablets $(n=8654)$. All subjects had a resting 12 lead electrocardiogram recorded at entry and every year subsequently and had serum potassium measured at entry and at one, three, and five years afterwards; those randomised to take bendrofluazide had additional potassium measurements three months, two years, and four years after entry. If serum potassium was below $3.5 \mathrm{mmol} / 1$ at entry examination, the patient was excluded from the trial. If the concentration fell on treatment to less than $2.4 \mathrm{mmol} / \mathrm{l}$, as happened in a few patients, diuretic treatment was stopped and oral potassium chloride was prescribed.

Each electrocardiogram was coded according to the Minnesota criteria ${ }^{7}$ so that important abnormalities could be recorded on computer. Each tracing was read by two observers who were blind to the treatment regimen; the second reader was also blind to the first reader's coding. If these two readers disagreed, a third reader was used. Only the first recorded change in any individual's electrocardiogram coding was used to calculate the incidence or reversion rates of electrocardiogram abnormalities. For instance, a person whose entry electrocardiogram was free of abnormal $Q$ waves but who showed such waves at the first anniversary was counted as an incidence case whether or not the change persisted in subsequent recordings. Similarly, a person whose tracings at entry and first anniversary showed abnormally tall $R$ waves, but whose second anniversary tracing did not, was counted as a reversion case whatever the picture in the later years.

Myocardial infarction was defined according to World Health Organisation criteria. ${ }^{8}$ Sudden death was defined as death within one hour of the onset of symptoms and was assumed to be caused by coronary heart disease unless postmortem examination showed some other cause. In the case of people found dead, it was usually possible to ascribe death to a sudden or not sudden category. In the small number of cases in which the timing was unknown, the case was included in the not sudden group. All events were assessed by an independent arbiter who was blind to the treatment regimen.
STATISTICAL ANALYSIS

\section{(a) Calculation of risk factors}

Multiple logistic regression was done on the conventional risk factors-age, systolic and diastolic blood pressure, serum cholesterol concentration, body mass index (body weight $/ \mathrm{height}^{2}$ in $\mathrm{kg} / \mathrm{m}^{2}$ ), electrocardiographic signs of ischaemia, and the number of cigarettes smoked. These factors were measured at entry to the trial and at intervals throughout the trial. For age and for electrocardiographic signs of ischaemia, entry data were used, while for the other variables the mean observed values throughout the trial were used.

The use of such in-treatment mean values increases the sensitivity of the analysis, and also gives estimates of relative risk that are unbiased by the effect of the selection process at screening. Calculated relative risks with respect to entry variables are to some extent biased by selection: for instance, despite repeated measurements being taken before entry, pressure still fell markedly during the early weeks of participation, ${ }^{1}$ presumably as the pressor effect of taking part in the trial diminished and as a result of regression to the mean. The data for the range of diastolic pressure once this process of familiarisation was largely complete indicate that the underlying range of pressure in trial subjects was less than that used as the entry criterion. The relative risk calculated for a given change of diastolic pressure in the present data is therefore correspondingly underestimated.

\section{(b) Significance of results}

Care is needed when $p$ values given as "significant" or not are interpreted. If the comparison is of prime importance, and might well have been considered so before the data were analysed, then it is appropriate to take the $p$ values at face value and adopt the conventional 0.05 value as the critical point, and this is the level indicated by the term "significant" used in the text. Interpretation, even of "significant" results of clear a priori importance, should be modified if the comparison is one of a number of correlated comparisons. In the absence of a priori importance a result with even a low $p$ value should be treated with caution as it has been obtained in the course of many subgroup analyses on many different variates. An appreciably lower $p$ value would be needed in such a case before significance could be ascribed to the relevant differences. These considerations explain why some comparisons have been fully discussed in the text while others have not. For full information an indication of the $p$ value has been given in the tables for levels of 0.05 to 0.1 in addition to the conventional mention of values $<0.05$. 
Medical Research Council Working Party on Mild Hypertension $\stackrel{\frac{m}{\Phi}}{\stackrel{T}{\Phi}}$

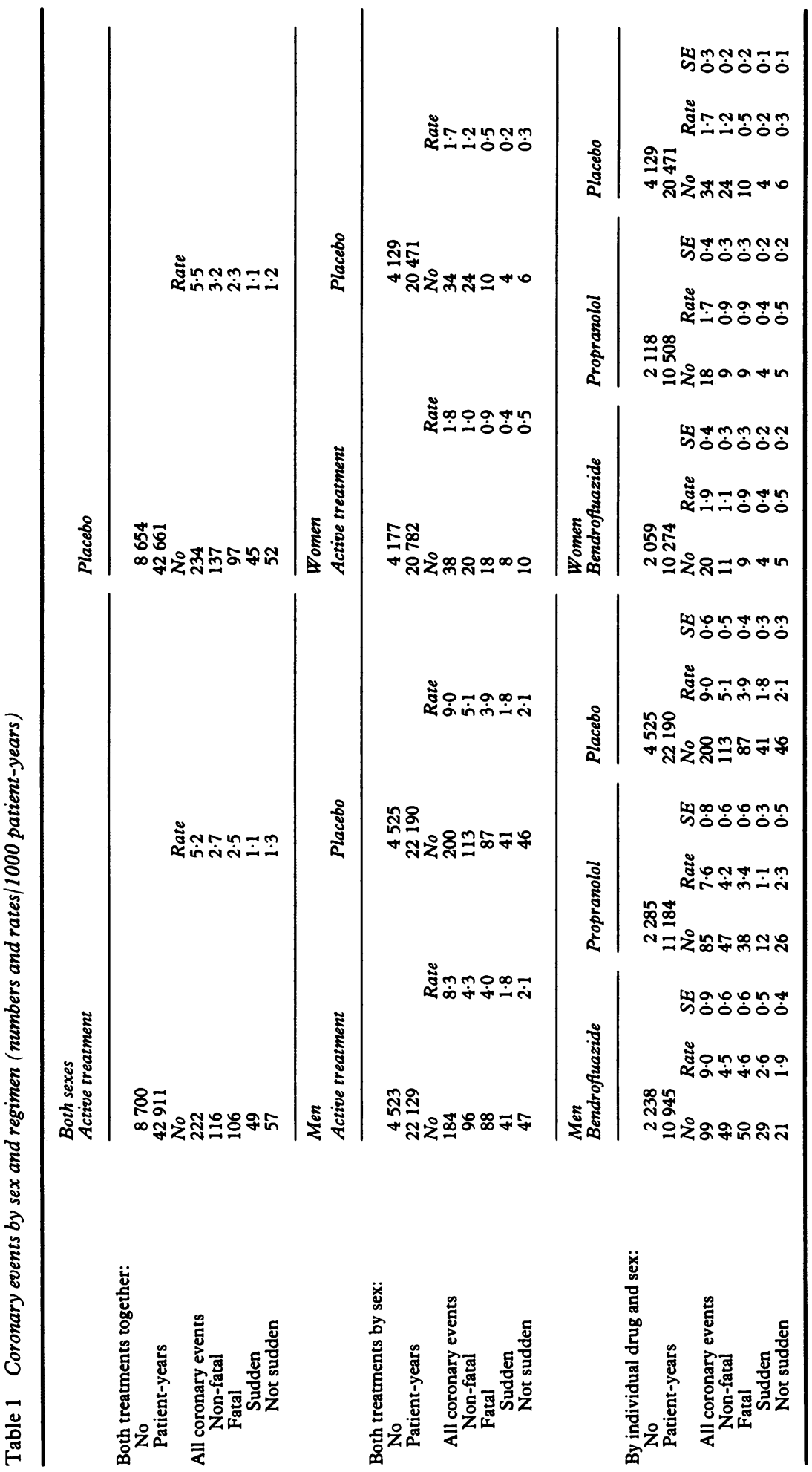




\section{Results}

MYOCARDIAL INFARCTION AND SUDDEN DEATH Table 1 shows the numbers and attack rates of fatal and non-fatal coronary events, with fatal events divided into sudden and not sudden, for both sexes and both treatments together and separately. There was a total of 456 events, 222 in people on active treatment ( 5.2 per thousand person-years) and 234 in those in the placebo group ( 5.5 per thousand personyears), giving no indication that the antihypertensive regimen had affected coronary event rates overall.

In all there were 384 events in men and only 72 in women (cumulative five and a half year percentages 4.7 and 0.9 , rates 8.7 and 1.7 per thousand personyears respectively). All categories of coronary events-that is non-fatal and fatal and both sudden and not sudden death-were more common in men than in women. One hundred and seventy five (46\%) events in men were fatal, and of these $82(47 \%)$ were sudden deaths. In women, $28(39 \%)$ of all events were fatal, and $12(43 \%)$ fatal cases were classified as sudden death. There were no significant differences between attack rates, in either sex, in any category, or on either active drug compared with placebo. Analysis by "on treatment" (as opposed to "as randomised") categories gave closely similar results.

Bendrofluazide in men-The overall coronary event rate of 9.0 per thousand person-years was the same as that in the placebo group (SE on bendrofluazide 0.9 and on placebo 0.6 ). When the events were subdivided into fatal and non-fatal, and sudden and not sudden, there were some small differences between the bendrofluazide and placebo rates, none of which approached statistical significance: (a) a small mean (SE) reduction in non-fatal event rates on the thiazide compared with the placebo $(4.5(0.6)$ vs $5 \cdot 1(0.5)$ per 1000 person-years); (b) a small increase in fatal event rates on the thiazide $(4.6(0.6)$ vs 3.9 $(0.4)$ per 1000 person-years); (c) a small increase in sudden death rates on the thiazide $(2.6(0.5)$ vs 1.8 $(0.3)$ per 1000 person-years); (d) a small increase in the percentage of all events on the thiazide that were sudden deaths (29\% vs $21 \%$ ). Analysis by "on treatment" categories gave closely similar results.

Propranolol in men-The mean (SE) overall rate was slightly but not significantly lower in this group than in the placebo group (7.6 (0.8) and 9.0 (0.6) per thousand person-years respectively). Other comparisons with the rate in the placebo group showed: $(a)$ a small decrease in non-fatal event rates on propranolol $(4.2(0.6)$ vs $5 \cdot 1(0.5)$ per 1000 person-years); (b) a small decrease in fatal event rates on propranolol (3.4 $(0.6)$ vs $3.9(0.4)$ per 1000 person-years); (c) a small decrease in sudden death rates on propranolol $(1 \cdot 1$ $(0.3)$ vs $1.8(0.3)$ per 1000 person-years); (d) a small decrease in the percentage of all events on propranolol that were sudden deaths $(14 \%$ vs $21 \%)$.

None of these differences approached conventional levels of significance. Whatever the treatment regimen, all rates in women were small and further analyses were uninformative.

Risk factors-Some information has already been published. ${ }^{1}$ More sensitive analyses have since been possible based on exact values (without categorisation) of on-treatment variables where appropriate, and some changes in the apparent importance of certain factors have become evident.

Table 2 shows the relative risks in relation to the conventional risk factors in men. Certain variables,

Table 2 Relation between conventional risk factors and the development of coronary events

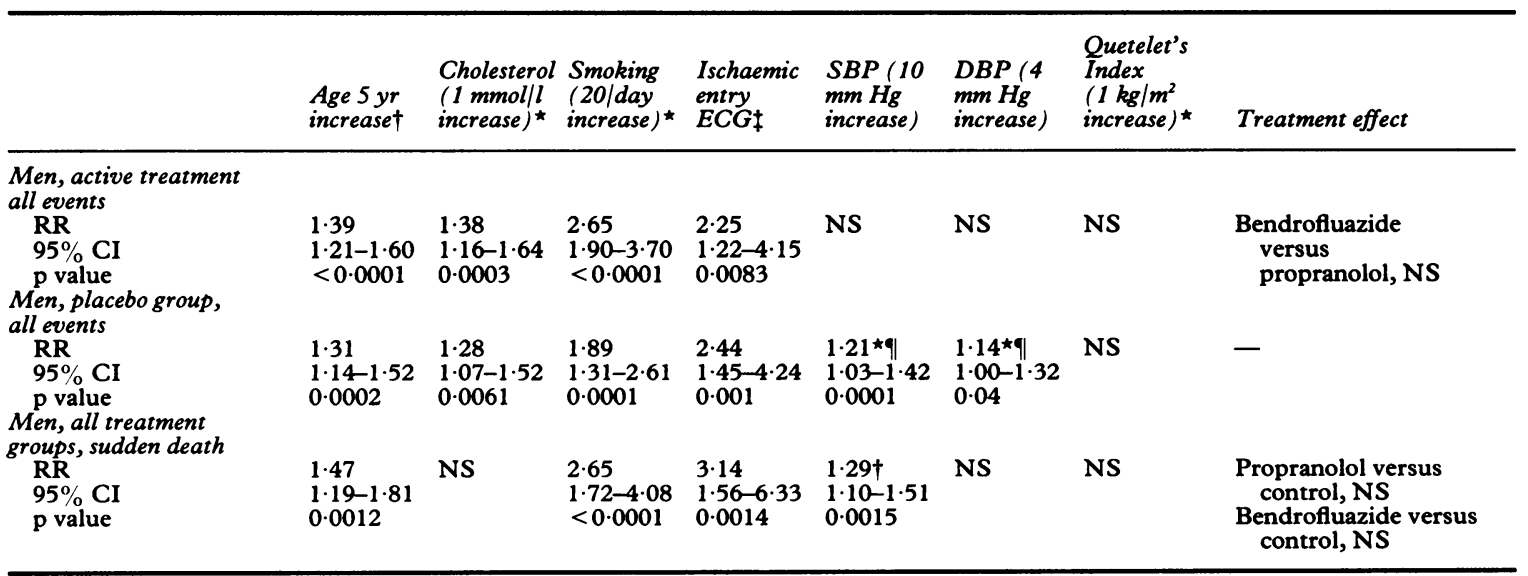

$\star$ Uses mean in-trial value. †Uses entry values.

$\ddagger 1_{1-2} 4_{1-3} 5_{1-2}$, one or more codes present.

The $\mathrm{p}$ value for each of these pressures is that for the inclusion of one factor before the other in a stepwise procedure; the CIs (confidence intervals) are calculated from the $t$ values from the model containing both pressures.

SBP, systolic blood pressure; DBP, diastolic blood pressure. 
such as cigarettes smoked and the concentration of serum cholesterol were used without being categorised (for example smoker/non-smoker) as was done in a previous paper ${ }^{1}$-that is they were used as continuous variables. Also, where appropriate, where repeated measurements of a risk variable were available throughout the trial the mean of these intreatment values was used, including for example the mean number of cigarettes smoked and the mean cholesterol concentration. We used entry values for age and for evidence of ischaemia in the electrocardiogram. In the previously published analysis body mass index at entry seemed to be a significant risk factor for coronary events. ${ }^{1}$ Though there is some suggestion that body mass index may be a significant variable for sudden death in women, for men the effects of body mass index in the current analysis, using the averaged and non-categorised risk variablesc described above, are not significant. A further limitation of previous analysis (that has now been $\stackrel{5}{?}$ overcome) was that the relative risks could not be obtained simultaneously from a single logistic regression model. These differences in technique $\overrightarrow{\widetilde{\sigma}}$ presumably account for the changed significance of body mass index.

Table 2 includes the results for all coronary events on the placebo. The pressure variable used is themean in-trial value, which best characterises prevail- $\vec{\omega}$ ing pressure during the period of observation. Both? systolic and diastolic pressure are significant risk? factors and the relative risks presented are for eache pressure individually. For actively treated patients $s_{\omega}^{\omega}$ pressures either at entry or in-trial were no longero significant risk factors.

Table 3 Coronary events by presence or absence of risk factor at entry (totals may be smaller than the overall total, because dat $\vec{a}$ on presence or absence of the risk factor were sometimes missing)

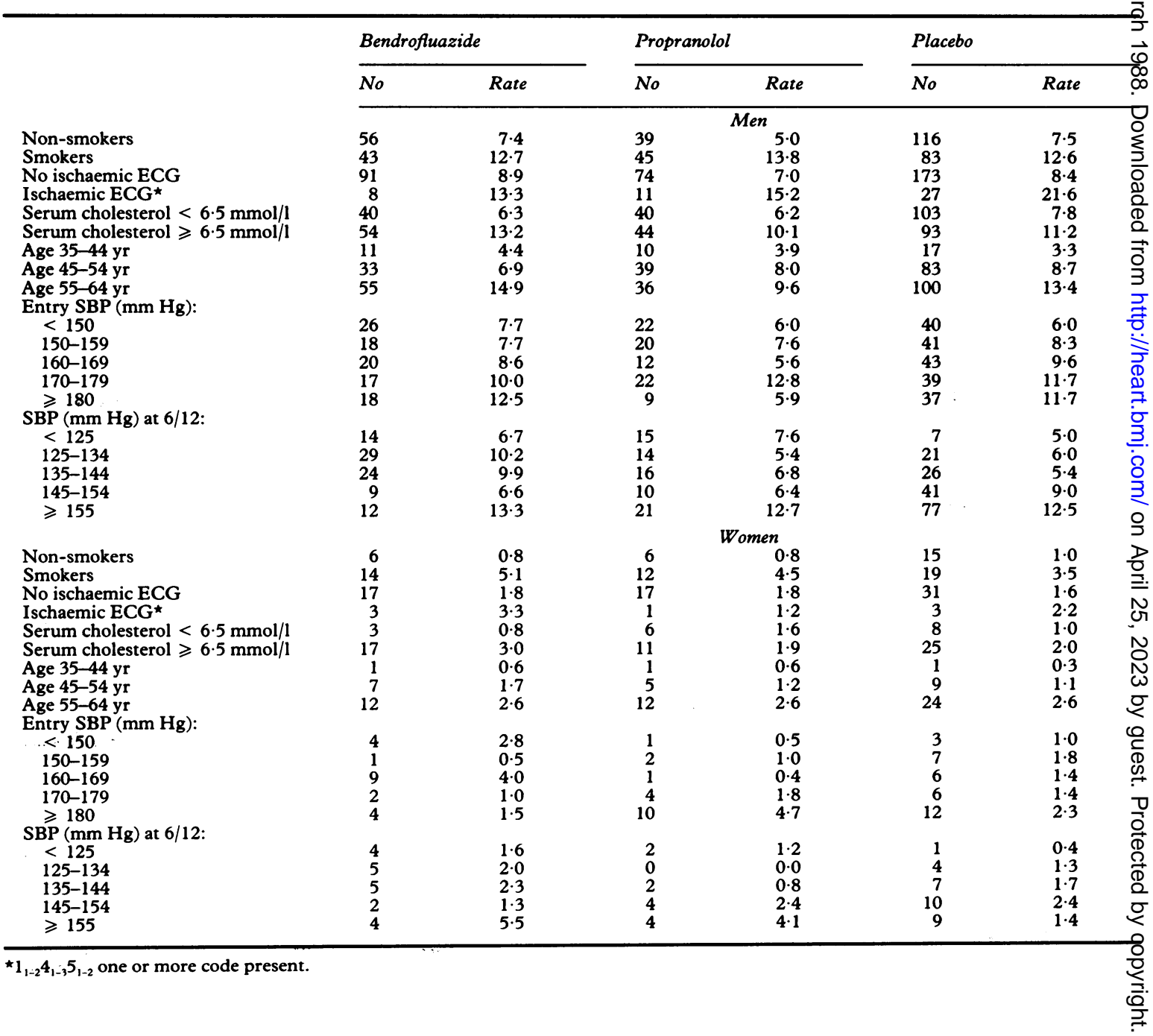


Table 2 also shows the relative risks for sudden death for all treatments. Entry pressure was used because it is not confounded with treatment effect (as in-trial pressure would be), and in fact the entry pressure does seem genuinely to have more predictive power for sudden death than in-trial pressure. The principal difference between the relative risks for all coronary events and sudden deaths is for serum cholesterol, which was not a significant risk factor for sudden death.

\section{SUBGROUPS DIVIDED BY STRENGTH OF RISK FACTOR (TABLE 3)}

With few exceptions that may be attributable to the small numbers of events in some subgroups, event rates rose with the strength of the risk factor in both actively treated groups as well as in people on placebo. (Although selection for the trial was based on diastolic pressure, in keeping with the emphasis placed on diastolic pressure in clinical practice, there is general agreement that systolic pressure is more strongly associated with the risk of coronary disease. Since the purpose of this section is to display event rates in terms of the main risk factors, systolic pressures have accordingly been used.)

The small reduction in coronary event rates associated with propranolol treatment in men was restricted to non-smokers in whom the rate in the treated group (5.0 per thousand person-years) was $33 \%$ less than that in the placebo group $(7.5$ per thousand person-years $)(p=0.04)$. In smokers given propranolol, treated and placebo rates were similar (13.8 and 12.6 per thousand person-years respectively). In a logistic regression analysis, however, an interaction analysis of treatment and smoking was not statistically significant $(p=0 \cdot 11)$.

Further, to investigate whether there was a doseresponse relation between the number of cigarettes smoked and the possible benefit associated with propranolol treatment, an on-treatment analysis was performed in which events were counted against the drug being taken when they occurred rather than that given at the time of randomisation, and smoking habit was categorised from cigarette consumption as recorded at the pre-event annual examination rather than at entry (table 4). The event rate did not consistently increase with the number of cigarettes smoked in any of the treatment groups. Both in the bendrofluazide and propranolol groups the rate in the non-smokers exceeded that in light smokers, and in the placebo group the rate in intermediate smokers was greater than that in men smoking 20 or more

Table 4 Relation between number of cigarettes smoked, as recorded at the last annual examination before the event, and treatment in men with analysis by treatment categorisation, not as randomised

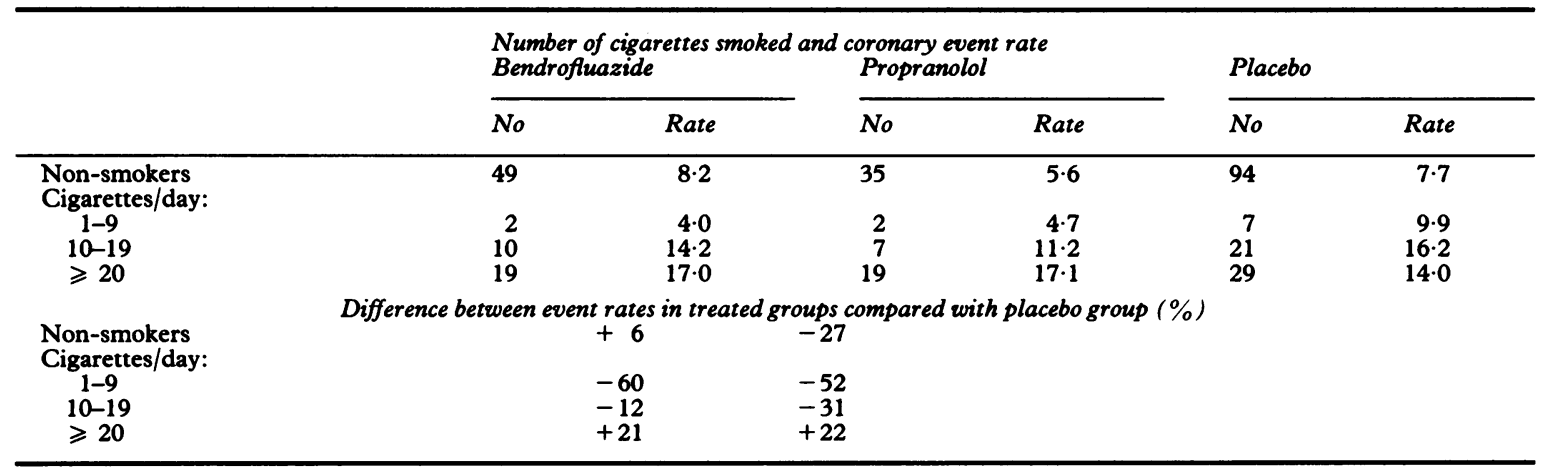

Table 5 Serum potassium (mmol/l) pre-event (sudden death) and in all subjects at first annual examination

\begin{tabular}{|c|c|c|c|c|c|c|}
\hline & \multicolumn{3}{|c|}{ Pre-sudden death } & \multicolumn{3}{|c|}{ First annual examination } \\
\hline & No & Mean & $S D$ & No & Mean & $S D$ \\
\hline $\begin{array}{l}\text { Bendrofluazide: } \\
\text { Men } \\
\text { Women }\end{array}$ & $\begin{array}{r}16 \\
3\end{array}$ & $\begin{array}{l}3.6 \\
3.8\end{array}$ & $\begin{array}{l}0.49 \\
0.53\end{array}$ & $\begin{array}{l}1988 \\
1829\end{array}$ & $\begin{array}{l}3.6 \\
3.5\end{array}$ & $\begin{array}{l}0.49 \\
0.50\end{array}$ \\
\hline $\begin{array}{l}\text { Propranolol: } \\
\text { Men } \\
\text { Women }\end{array}$ & $\begin{array}{l}4 \\
3\end{array}$ & $\begin{array}{l}4 \cdot 4 \\
4 \cdot 3\end{array}$ & $\begin{array}{l}0.61 \\
0.26\end{array}$ & $\begin{array}{l}1999 \\
1844\end{array}$ & $\begin{array}{l}4 \cdot 2 \\
4 \cdot 2\end{array}$ & $\begin{array}{l}0.41 \\
0.44\end{array}$ \\
\hline $\begin{array}{l}\text { Placebo: } \\
\text { Men } \\
\text { Women }\end{array}$ & 22 & $\begin{array}{l}4 \cdot 1 \\
4 \cdot 2\end{array}$ & $\begin{array}{l}0.80 \\
0.00\end{array}$ & $\begin{array}{l}3990 \\
3637\end{array}$ & $\begin{array}{l}4 \cdot 1 \\
4 \cdot 1\end{array}$ & $\begin{array}{l}0.37 \\
0.38\end{array}$ \\
\hline
\end{tabular}


cigarettes daily. Analysis of the change in event rate by number of cigarettes smoked did not show a consistent trend within the propranolol group, where the percentage reduction was greater in light smokers than in the non-smokers. Only in the heaviest smokers was there no suggestion of benefit associated with propranolol treatment. The results in the bendrofluazide group, in which no overall benefit associated with treatment was suggested, were similar in that the rate in non-smokers was higher than that in the placebo group whereas that in light smokers was lower, and only in the heaviest smokers was there a clear excess of events in the treated group in comparison with the controls.

No specific hazard attached to bendrofluazide treatment when ischaemic changes were seen on the electrocardiogram at entry. Rates for men were 13.3 per thousand person-years in the bendrofluazide group compared with 15.2 on propranolol and 21.6 in the placebo group.

\section{RELATION BETWEEN SERUM POTASSIUM CONCENTRATIONS AND SUDDEN DEATH (TABLE 5)}

The mean concentrations of serum potassium (in an on-treatment analysis) at the anniversary examination preceding sudden death were compared with those in the complete treatment groups (as opposed to subgroups) at the first anniversary of entry. There were no significant differences, in any treatment regimen, between the concentrations in the sudden death category compared with those in all patients.

\section{EVENT RATES BY DURATION OF TREATMENT}

(TABLE 6) during the first year of follow up in men on bendrofluazide was caused by a difference in the sudden deaths category - there were six deaths in the bendrofluazide group compared with three in the $\triangle$ placebo group which was twice the size of the is bendrofluazide group. This excess was not statis- $\vec{\circ}$ tically significant $(p=0.08)$. There were three nonsudden deaths in the first year on the diuretic $\vec{\omega}$ compared with eight in the placebo group, and $16 \frac{\mathrm{O}}{\partial}$ non-fatal events on bendrofluazide compared with 32 on placebo; these results do not suggest any hazard 0 associated with active treatment. There was no $\omega$ evidence of a trend in event rate with time on $\underset{\perp}{\oplus}$ bendrofluazide. The postulated protective effect of propranolol was apparently greatest in the first year of treatment, but the difference between the strength $\bar{z}$ of this possible effect in the first year and in other years was not significant.

EVENT RATES BY PULSE RATE AT ENTRY OR AT THE ANNUAL EXAMINATION PRECEDING THE EVENT (TABLE 7)

These results were inconsistent. In the placebo group, although pre-event pulse rate and event rate were apparently related, entry pulse rate and event rate were not. On bendrofluazide, entry pulse rate was possibly related to event rate, but pre-event pulse rate was not. On propranolol, pulse rate both at entry and at the pre-event measurement was possibly related to event rate.

Table 6 Percentage event rates by year in trial ${ }^{\star}$ for men

\begin{tabular}{|c|c|c|c|c|c|c|}
\hline \multirow[b]{2}{*}{ Event/time in trial } & \multicolumn{2}{|c|}{ Bendrofluazide } & \multicolumn{2}{|c|}{ Propranolol } & \multicolumn{2}{|c|}{ Placebo } \\
\hline & No & $\%$ & No & $\%$ & No & $\%$ \\
\hline \multicolumn{7}{|l|}{ All coronary events: } \\
\hline $\begin{array}{l}\text { 1st year } \\
\text { 2nd year } \\
\text { 3rd year } \\
\text { 4th year } \\
\text { 5th year }\end{array}$ & $\begin{array}{r}25 \\
19 \\
21 \\
18 \\
9\end{array}$ & $\begin{array}{l}1 \cdot 12 \\
0.86 \\
0.97 \\
0.89 \\
0.60\end{array}$ & $\begin{array}{r}10 \\
18 \\
19 \\
25 \\
8\end{array}$ & $\begin{array}{l}0.44 \\
0.80 \\
0.86 \\
1.23 \\
0.58\end{array}$ & $\begin{array}{l}43 \\
39 \\
49 \\
40 \\
22\end{array}$ & $\begin{array}{l}0.95 \\
0.88 \\
1.11 \\
0.98 \\
0.72\end{array}$ \\
\hline \multicolumn{7}{|l|}{ Fatal events: } \\
\hline $\begin{array}{l}\text { 1st year } \\
\text { 2nd year } \\
\text { 3rd year } \\
\text { 4th year } \\
\text { 5th year }\end{array}$ & $\begin{array}{r}9 \\
8 \\
14 \\
11 \\
4\end{array}$ & $\begin{array}{l}0.40 \\
0.36 \\
0.64 \\
0.55 \\
0.26\end{array}$ & $\begin{array}{r}3 \\
8 \\
8 \\
11 \\
3\end{array}$ & $\begin{array}{l}0.12 \\
0.36 \\
0.35 \\
0.53 \\
0.21\end{array}$ & $\begin{array}{l}11 \\
17 \\
20 \\
23 \\
10\end{array}$ & $\begin{array}{l}0 \cdot 23 \\
0 \cdot 38 \\
0 \cdot 45 \\
0 \cdot 56 \\
0 \cdot 33\end{array}$ \\
\hline \multicolumn{7}{|l|}{ Sudden deaths: } \\
\hline $\begin{array}{l}\text { 1st year } \\
\text { 2nd year } \\
\text { 3rd year } \\
\text { 4th year } \\
\text { 5th year }\end{array}$ & $\begin{array}{l}6 \\
3 \\
8 \\
7 \\
3\end{array}$ & $\begin{array}{l}0 \cdot 26 \\
0 \cdot 13 \\
0 \cdot 37 \\
0 \cdot 36 \\
0 \cdot 20\end{array}$ & $\begin{array}{l}0 \\
4 \\
3 \\
3 \\
1\end{array}$ & $\begin{array}{l}0 \cdot 00 \\
0 \cdot 18 \\
0 \cdot 13 \\
0 \cdot 14 \\
0 \cdot 07\end{array}$ & $\begin{array}{r}3 \\
13 \\
6 \\
10 \\
6\end{array}$ & $\begin{array}{l}0.06 \\
0.29 \\
0.13 \\
0.24 \\
0.19\end{array}$ \\
\hline
\end{tabular}

*Some events occurred after the fifth anniversary. 
Table 7 Coronary event rates (per 1000 person-years) by pulse rate (men)

\begin{tabular}{|c|c|c|c|c|c|c|}
\hline & \multicolumn{2}{|c|}{ Bendrofluazide } & \multicolumn{2}{|c|}{ Propranolol } & \multicolumn{2}{|c|}{ Placebo } \\
\hline & No & Rate & No & Rate & No & Rate \\
\hline $\begin{array}{c}\text { Entry puls } \\
<65 \\
65-74 \\
75-84 \\
85-94 \\
\geqslant 95\end{array}$ & $\begin{array}{r}6 \\
16 \\
43 \\
17 \\
14\end{array}$ & $\begin{array}{r}7.0 \\
6.4 \\
9.8 \\
10.9 \\
12.2\end{array}$ & $\begin{array}{r}4 \\
14 \\
36 \\
15 \\
12\end{array}$ & $\begin{array}{l}3.9 \\
5.5 \\
8.2 \\
8.8 \\
9.2\end{array}$ & $\begin{array}{l}18 \\
36 \\
80 \\
39 \\
25\end{array}$ & $\begin{array}{r}10 \cdot 4 \\
7 \cdot 1 \\
9 \cdot 0 \\
11 \cdot 2 \\
11 \cdot 5\end{array}$ \\
\hline $\begin{array}{c}\text { Pre-event } \\
<65 \\
65-74 \\
75-84 \\
85-94 \\
\geqslant 95\end{array}$ & $\begin{array}{r}13 \\
19 \\
43 \\
16 \\
8\end{array}$ & $\begin{array}{r}9 \cdot 2 \\
7 \cdot 1 \\
9 \cdot 8 \\
10 \cdot 4 \\
8 \cdot 8\end{array}$ & $\begin{array}{r}17 \\
26 \\
29 \\
10 \\
3\end{array}$ & $\begin{array}{r}4.8 \\
8.3 \\
9.5 \\
11.7 \\
5.5\end{array}$ & $\begin{array}{l}20 \\
43 \\
85 \\
32 \\
20\end{array}$ & $\begin{array}{r}8 \cdot 1 \\
8 \cdot 1 \\
9 \cdot 4 \\
9 \cdot 3 \\
11 \cdot 9\end{array}$ \\
\hline
\end{tabular}

^Pulse rate recorded at the anniversary examination preceding the event.

The rates in women were too low for subgroup analyses to be informative.

\section{ELECTROCARDIOGRAPHIC ABNORMALITIES}

Full details are shown in the tables, and only those points of particular interest with strong statistical significance will be described here.

The prevalence of major electrocardiographic abnormalities at entry was low and was closely similar in men and women, and in smokers and nonsmokers (table 8). Treatment with bendrofluazide (tables 9 and 10) reduced the incidence of abnormally tall $\mathbf{R}$ waves in men and women $\left(\mathrm{p}<10^{-4}\right)$ and increased the incidence of combined ST-segment and $T$-wave abnormalities in women $\left(p<10^{-4}\right)$. On propranolol, the incidence of $T$-wave inversion without ST segment changes was increased in women $\left(\mathrm{p}<10^{-4}\right)$. When the data were divided by smoking habit (tables 11 and 12) these findings were less evident in smokers, possibly because these were the smaller groups. In men on propranolol, the frequency of combined ST-segment and $\mathrm{T}$-wave abnormality was greater in smokers than in nonsmokers $(\mathrm{p}=0.0001)$.

There were considerable differences between the incidence of ventricular extrasystoles when the data were divided by sex, by treatment regimen, and by duration of follow up (table 13). There was no evidence that there was a trend with time in any treatment group or that the groups differed from one another in this respect.

Coronary events were more common in the group with any of the following abnormalities-major $Q /$ QS abnormality, minor Q/QS abnormality, abnormally tall $R$ waves, $S T$-segment depression, $T$-wave flattening or inversion, "strain" with tall $R$ waves associated with ST-T abnormalities, ventricular extrasystoles totalling $10 \%$ or more of all recorded complexes-than in the group with normal electrocardiograms (relative risk $1.48,95 \%$ confidence interval (CI) 1.17 to 1.86 ). Among the individual features, major abnormalities of the $\mathrm{Q} / \mathrm{QS}$ waves (relative risk $2 \cdot 29, \mathrm{CI} 1.21$ to 4.34 ), ST segment depression with $T$-wave inversion (relative risk $2 \cdot 59$, CI 1.43 to 4.71 ), $\mathrm{T}$-wave inversion (relative risk 2.54 , CI 1.53 to 4.23 ), and "strain" with tall $R$ waves together with these ST-T manifestations (relative risk 3.49 , CI 1.20 to 10.21 ), made statistically significant contributions. Minor $\mathrm{Q} / \mathrm{QS}$ abnormalities, tall $\mathbf{R}$ waves in the absence of abnormal ST-T tracings, and ventricular extrasystoles totalling $10 \%$ or more of all recorded complexes were not statistically significant risk factors. "On treatment" analysis gave similar results.

\section{COMPARISONS BETWEEN BENDROFLUAZIDE AND} PROPRANOLOL

There are many occasions where, because the rates on the two drugs differ in opposite directions from that on the placebo, the between-drug comparisons show larger differences than do comparisons of the active drug with the placebo. These comparisons between drugs add little where the individual drug rates differ from the rates in the placebo group with a p value $<0 \cdot 1$, since these more direct results could be used as the basis for a choice between drugs. For information, $p$ values for between-drug differences none the less have been shown in all tables where they are $<0 \cdot 1$. Not all will be enumerated here, but the following are of possible interest:

(a) Sudden death in men (table 1)-The rate on bendrofluazide was 2.6 per 1000 person-years, and that on propranolol was $1 \cdot 1$ per 1000 person-years (for the comparison of either of these rates with the rate in the placebo group of 1.8 per 1000 person-years $p>0 \cdot 1)$. For the bendrofluazide compared with the 
Table 8 Percentage prevalence of major electrocardiographic abnormalities at entry (one person may appear more than once in $\stackrel{\overrightarrow{+}}{\mathrm{C}}$ this table). (Rates given per 100 entrants)

\begin{tabular}{|c|c|c|c|c|c|c|c|c|c|c|c|c|}
\hline & & & & & \multicolumn{4}{|l|}{ Men } & \multicolumn{4}{|c|}{ Women } \\
\hline & & & & & \multicolumn{2}{|l|}{ No } & \multicolumn{2}{|l|}{ Rate } & \multicolumn{2}{|l|}{ No } & \multicolumn{2}{|l|}{ Rate } \\
\hline \multirow{3}{*}{\multicolumn{5}{|c|}{$\begin{array}{l}\text { By sex: } \\
\text { More definite abnormal Q/QS items compatible with infarction } \\
\text { Less definite changes suggesting infarction } \\
\text { Abnormally tall } \mathrm{R} \text { waves } \\
\text { ST segment depressed or downward sloping, } \mathrm{T} \text { wave inverted } \\
\text { LVH and strain } \\
\text { T wave inverted, ST segment normal } \\
\text { T wave minimally inverted or flat, } S T \text { segment normal } \\
\geqslant 10 \% \text { recorded complexes are ventricular extrasystoles }\end{array}$}} & $\begin{array}{r}118 \\
184 \\
542 \\
114 \\
31 \\
57 \\
380 \\
36\end{array}$ & & $\begin{array}{l}1 \cdot 3 \\
2.0 \\
6.0 \\
1.3 \\
0.3 \\
0.6 \\
4.2 \\
0.4\end{array}$ & & $\begin{array}{r}128 \\
163 \\
373 \\
146 \\
25 \\
55 \\
351 \\
51\end{array}$ & & $\begin{array}{l}1.5 \\
2.0 \\
4.5 \\
1.8 \\
0.3 \\
0.7 \\
4.2 \\
0.6\end{array}$ & \\
\hline & & & & & $S$ & & $N S$ & & $S$ & & $N S$ & \\
\hline & & & & & No & Rate & No & Rate & No & Rate & No & Rate \\
\hline \multicolumn{5}{|c|}{$\begin{array}{l}\text { By smoking ( } \mathrm{S} \text {, smokers; } \mathrm{NS} \text {, non-smokers): } \\
\text { More definite abnormal } \mathrm{Q} / \mathrm{Q} \text { items compatible with infarction } \\
\text { Less definite changes suggesting infarction } \\
\text { Abnormally tall } \mathrm{R} \text { waves } \\
\text { ST segment depressed or downward sloping, } \mathrm{T} \text { wave inverted } \\
\mathrm{LVH} \text { and strain } \\
\mathrm{T} \text { wave inverted, ST segment normal } \\
\mathrm{T} \text { wave minimally inverted or flat, } \mathrm{ST} \text { segment normal } \\
\geqslant 10 \% \text { recorded complexes are ventricular extrasystoles }\end{array}$} & $\begin{array}{r}38 \\
55 \\
137 \\
32 \\
8 \\
15 \\
129 \\
7\end{array}$ & $\begin{array}{l}1.4 \\
2.0 \\
4.9 \\
1.1 \\
0.3 \\
0.5 \\
4.6 \\
0.2\end{array}$ & $\begin{array}{r}79 \\
128 \\
402 \\
81 \\
23 \\
41 \\
250 \\
29\end{array}$ & $\begin{array}{l}1 \cdot 3 \\
2 \cdot 1 \\
6 \cdot 5 \\
1.3 \\
0 \cdot 4 \\
0.7 \\
4 \cdot 1 \\
0.5\end{array}$ & $\begin{array}{r}35 \\
48 \\
62 \\
38 \\
4 \\
13 \\
103 \\
22\end{array}$ & $\begin{array}{l}1 \cdot 6 \\
2 \cdot 2 \\
2 \cdot 8 \\
1 \cdot 7 \\
0 \cdot 2 \\
0.6 \\
4.7 \\
1.0\end{array}$ & $\begin{array}{r}92 \\
114 \\
309 \\
108 \\
21 \\
42 \\
246 \\
29\end{array}$ & $\begin{array}{l}1.5 \\
1.9 \\
5.1 \\
1.8 \\
0.3 \\
0.7 \\
4.1 \\
0.5\end{array}$ \\
\hline & \multicolumn{6}{|c|}{ Men } & \multicolumn{6}{|c|}{ Women } \\
\hline & \multicolumn{2}{|c|}{$\begin{array}{l}\text { Bendro- } \\
\text { fluazide }\end{array}$} & \multicolumn{2}{|c|}{$\begin{array}{l}\text { Propra- } \\
\text { nolol }\end{array}$} & \multicolumn{2}{|c|}{ Placebo } & \multicolumn{2}{|c|}{$\begin{array}{l}\text { Bendro- } \\
\text { fluazide }\end{array}$} & \multicolumn{2}{|c|}{$\begin{array}{l}\text { Propra- } \\
\text { nolol }\end{array}$} & \multicolumn{2}{|c|}{ Placebo } \\
\hline & No & Rate & No & Rate & No & Rate & No & Rate & No & Rate & No & Rate \\
\hline \multirow{6}{*}{$\begin{array}{l}\text { By randomised regimen: } \\
\text { More definite abnormal } Q / Q S \text { items } \\
\text { compatible with infarction } \\
\text { Less definite changes } \\
\text { suggesting infarction } \\
\text { Abnormally tall } R \text { waves } \\
\text { ST segment depressed or downward } \\
\text { sloping, T wave inverted } \\
\text { LVH and strain } \\
T \text { wave inverted, } S T \text { segment } \\
\text { normal } \\
T \text { wave minimally inverted or } \\
\text { flat, ST segment normal } \\
\geqslant 10 \% \text { recorded complexes are } \\
\text { ventricular extrasystoles }\end{array}$} & 23 & 1.0 & 27 & $1 \cdot 2$ & 68 & 1.5 & 36 & $1 \cdot 8$ & 35 & $1 \cdot 7$ & 57 & $1 \cdot 4$ \\
\hline & $\begin{array}{r}49 \\
120 \\
33\end{array}$ & $\begin{array}{l}2 \cdot 2 \\
5 \cdot 4 \\
\end{array}$ & $\begin{array}{r}40 \\
146\end{array}$ & $\begin{array}{l}1 \cdot 8 \\
6.4\end{array}$ & $\begin{array}{r}95 \\
276\end{array}$ & $\begin{array}{l}2 \cdot 1 \\
6 \cdot 1\end{array}$ & $\begin{array}{l}40 \\
87\end{array}$ & $\begin{array}{l}1.9 \\
4.2\end{array}$ & $\begin{array}{l}38 \\
91\end{array}$ & $\begin{array}{l}1 \cdot 8 \\
4 \cdot 3\end{array}$ & $\begin{array}{r}85 \\
195\end{array}$ & $\begin{array}{l}2 \cdot 1 \\
4 \cdot 7\end{array}$ \\
\hline & $\begin{array}{r}33 \\
9\end{array}$ & $\begin{array}{l}1.5 \\
0.4\end{array}$ & $\begin{array}{r}24 \\
6\end{array}$ & $\begin{array}{l}1 \cdot 1 \\
0 \cdot 3\end{array}$ & $\begin{array}{l}57 \\
16\end{array}$ & $\begin{array}{l}1 \cdot 3 \\
0 \cdot 4\end{array}$ & $\begin{array}{r}43 \\
5\end{array}$ & $\begin{array}{l}2 \cdot 1 \\
0 \cdot 2\end{array}$ & $\begin{array}{r}29 \\
5\end{array}$ & $\begin{array}{l}1.4 \\
0.2\end{array}$ & $\begin{array}{l}74 \\
15\end{array}$ & $\begin{array}{l}1.8 \\
0.4\end{array}$ \\
\hline & 9 & 0.4 & 15 & $0 \cdot 7$ & 33 & 0.7 & 14 & 0.7 & 16 & 0.8 & 25 & 0.6 \\
\hline & 90 & $4 \cdot 0$ & 111 & $4 \cdot 9$ & 179 & $4 \cdot 0$ & 90 & $4 \cdot 4$ & 105 & $5 \cdot 0$ & 156 & 3.8 \\
\hline & 8 & $0 \cdot 4$ & 9 & 0.4 & 19 & 0.4 & 12 & 0.6 & 14 & $0 \cdot 7$ & 25 & 0.6 \\
\hline
\end{tabular}

«Totals are not always the same as in the other two parts of the table because in a small number of people the smoking habit at entry was unknown.

LVH, left ventricular hypertrophy.

propranolol rate, however, $\mathrm{p}=0.01$.

(b) Major $Q / Q S$ changes in women (table 9)-On bendrofluazide the rate was 13.5 per 1000 personyears, compared with 9.8 per 1000 person-years on propranolol $(\mathrm{p}=0.04)$.

(c) Tall $R$ waves (table 9)-In men the rate per 1000 person-years on bendrofluazide was less than that on propranolol $(14.2$ vs 18.2, $\mathrm{p}=0.05)$; in women the respective rates per 1000 person-years were 9.3 vs $15.6(\mathrm{p}=0.0005)$.

(d) Ventricular extrasystoles amounting to $>10 \%$ of all complexes in men (table 9)-For bendrofluazide the rate was 6.7 per 1000 person-years, similar to the placebo rate of 6.4 per 1000 person-years. For propranolol the rate was 4.5 per 1000 person-years, $p=0.08$ compared with the placebo group. For the bendrofluazide $v s$ the propranolol rate, $p=0.08$.

\section{Discussion}

The frequency of coronary heart disease in this population corresponds well with that in other comparable series, with coronary event rates close to those in the Australian study ${ }^{3}$ and the Oslo trial. ${ }^{9}$ As with any trial, the results are strictly applicable only to the study population. We cannot be certain that 
Table 9 Incidence of major electrocardiographic (ECG) abnormalities during follow up (numbers and rates per thousand person-years)

\begin{tabular}{|c|c|c|c|c|c|c|c|c|c|c|c|c|}
\hline \multirow[b]{2}{*}{ ECG abnormality } & \multicolumn{6}{|l|}{ Men } & \multicolumn{6}{|c|}{ Women } \\
\hline & $\begin{array}{l}\text { Bendrof } \\
\text { No }\end{array}$ & $\begin{array}{l}\text { fluazide } \\
\text { Rate }\end{array}$ & $\begin{array}{l}\text { Propr } \\
\text { No }\end{array}$ & $\begin{array}{l}\text { molol } \\
\text { Rate }\end{array}$ & $\begin{array}{l}\text { Placebo } \\
\text { No }\end{array}$ & Rate & $\begin{array}{l}\text { Bend } \\
\text { No }\end{array}$ & Rate & $\begin{array}{l}\text { Prop } \\
\text { No }\end{array}$ & $\begin{array}{l}\text { molol } \\
\text { Rate }\end{array}$ & $\begin{array}{l}\text { Placebo } \\
\text { No }\end{array}$ & Rate \\
\hline $\begin{array}{l}\text { Major Q/QS } \\
\text { abnormalities } \\
\text { Minor Q/QS }\end{array}$ & 109 & $13 \cdot 2^{\star}$ & 84 & $9 \cdot 8 \dagger$ & 169 & $10 \cdot 0$ & 105 & 13.5 & 78 & $9 \cdot 8 \dagger$ & 190 & $12 \cdot 1$ \\
\hline $\begin{array}{l}\text { abnormalities } \\
\text { Tall } R\end{array}$ & 80 & $10 \cdot 3$ & 59 & $7 \cdot 2 \dagger$ & 135 & $8 \cdot 5$ & 73 & $10 \cdot 0$ & 57 & $7 \cdot 5^{\circ}$ & 148 & $10 \cdot 1$ \\
\hline $\begin{array}{l}\text { waves } \\
\text { ST depression, } T \text {-wave }\end{array}$ & 113 & $14 \cdot 2^{\star \star \star}$ & 146 & $18 \cdot 2^{\star \bullet}$ & 367 & $23 \cdot 3$ & 71 & $9 \cdot 3 \star \star \star$ & 121 & $15 \cdot 6^{\circ}$ & 283 & $18 \cdot 9$ \\
\hline $\begin{array}{l}\text { inversion } \\
\mathrm{LVH} \text { and strain } \\
\mathrm{T} \text { wave inverted, ST } \\
\text { segment }\end{array}$ & $\begin{array}{l}82 \\
16\end{array}$ & $\begin{array}{l}9.8 \\
1.9\end{array}$ & $\begin{array}{l}62 \\
16\end{array}$ & $\begin{array}{l}7 \cdot 1^{\star \star \bullet} \\
1 \cdot 8\end{array}$ & $\begin{array}{r}194 \\
46\end{array}$ & $\begin{array}{r}11 \cdot 4 \\
2 \cdot 6\end{array}$ & $\begin{array}{r}145 \\
8\end{array}$ & $\begin{array}{l}19 \cdot 0^{\star \star \star} \\
1 \cdot 0^{\star}\end{array}$ & $\begin{array}{l}91 \\
15\end{array}$ & $\begin{array}{c}11.4+t \dagger \\
1.8\end{array}$ & $\begin{array}{r}172 \\
41\end{array}$ & $\begin{array}{r}10 \cdot 8 \\
2.5\end{array}$ \\
\hline $\begin{array}{l}\text { normal } \\
T \text { wave flat or minimally } \\
\text { inverted, ST seoment }\end{array}$ & 32 & $3 \cdot 9 \star$ & 59 & $7 \cdot 0 \dagger$ & 109 & $6 \cdot 7$ & 46 & $6 \cdot 4^{\star}$ & 81 & $10 \cdot 6+t \star \star \star$ & 60 & 3.9 \\
\hline $\begin{array}{l}\text { normal } \\
\text { Ventricular extrasystoles }\end{array}$ & 128 & $17 \cdot 8^{\star \star}$ & 148 & $19 \cdot 8^{\star}$ & 363 & $24 \cdot 9$ & 180 & $30 \cdot 6^{\star}$ & 168 & $26 \cdot 3$ & 332 & $25 \cdot 4$ \\
\hline complexes & 57 & $6 \cdot 7$ & 40 & $4.5^{\circ} \bullet$ & 110 & 6.4 & 49 & $6 \cdot 1$ & 39 & $4 \cdot 7$ & 80 & 4.9 \\
\hline
\end{tabular}

${ }_{p}<0.1 ;{ }^{\star} p<0.05 ;{ }^{\star \star} p<0.01 ;{ }^{\star \star \star} p<0.001$; for comparison of rate in actively treated group against placebo.

${ }^{\circ} \mathrm{p}<0.1 ; \dagger \mathrm{p}<0.05 ; \dagger+\mathrm{p}<0.01 ; \dagger+\dagger \mathrm{p}<0.001$; for comparison of rate in one actively treated group with the other.

the findings would have been identical in a group characterised, for example, by a higher proportion of smokers or by less of a tendency towards a spontaneous decline in blood pressure from entry levels, but it seems unlikely that they would be qualitatively different.

Drug treatment had no effect on the rate of coronary heart disease overall and, although there are suggestions in the present data that both the active drugs may have been associated with benefits, the results must be interpreted with great care. If true, the suggestion that propranolol reduced the attack rate of coronary events in male non-smokers would be of considerable importance, but our data are

Table 10 Reversion rates of major electrocardiographic (ECG) abnormalities during follow up (numbers and rates per thousand person-years)

\begin{tabular}{|c|c|c|c|c|c|c|c|c|c|c|c|c|}
\hline \multirow[b]{3}{*}{ ECG abnormality } & \multicolumn{6}{|c|}{ Men } & \multicolumn{6}{|c|}{ Women } \\
\hline & \multicolumn{2}{|c|}{ Bendrofluazide } & \multicolumn{2}{|c|}{ Propranolol } & \multicolumn{2}{|c|}{ Placebo } & \multicolumn{2}{|c|}{ Bendrofluazide } & \multicolumn{2}{|c|}{ Propranolol } & \multicolumn{2}{|c|}{ Placebo } \\
\hline & No & Rate & No & Rate & No & Rate & No & Rate & No & Rate & No & Rate \\
\hline $\begin{array}{l}\text { Major Q/QS } \\
\text { abnormality } \\
\text { Minor Q/QS }\end{array}$ & 18 & 455.9 & 20 & $465 \cdot 1$ & 47 & 365.4 & 27 & $651 \cdot 6$ & 31 & $500 \cdot 0$ & 46 & $598 \cdot 8$ \\
\hline $\begin{array}{l}\text { abnormality } \\
\text { Tall } \mathbf{R}\end{array}$ & 36 & $690 \cdot 0$ & 27 & $467 \cdot 6$ & 63 & 563.6 & 29 & $537 \cdot 0$ & 26 & $520 \cdot 0$ & 62 & $632 \cdot 6$ \\
\hline $\begin{array}{l}\text { waves } \\
\text { ST-T abnormalities } \\
\text { Strain } \\
\text { T wave inverted, }\end{array}$ & $\begin{array}{r}96 \\
23 \\
7\end{array}$ & $\begin{array}{l}440 \cdot 7^{\circ} \\
465 \cdot 6 \\
777 \cdot 8\end{array}$ & $\begin{array}{r}111 \\
15 \\
5\end{array}$ & $\begin{array}{l}502 \cdot 4^{\star \star} \\
333 \cdot 3 \\
454 \cdot 5\end{array}$ & $\begin{array}{r}195 \\
33 \\
13\end{array}$ & $\begin{array}{l}354 \cdot 3 \\
363 \cdot 8 \\
722 \cdot 2\end{array}$ & $\begin{array}{r}62 \\
36 \\
5\end{array}$ & $\begin{array}{l}427 \cdot 7 \\
432 \cdot 9 \\
714 \cdot 3\end{array}$ & $\begin{array}{r}63 \\
21 \\
5\end{array}$ & $\begin{array}{l}364 \cdot 2 \\
416 \cdot 8 \\
625 \cdot 0\end{array}$ & $\begin{array}{r}137 \\
55 \\
13\end{array}$ & $\begin{array}{l}344 \cdot 6 \\
458 \cdot 4 \\
565 \cdot 2\end{array}$ \\
\hline $\begin{array}{l}\text { normal } \\
\text { wave flat or } \\
\text { minimally } \\
\text { inverted, } \\
\text { ST segment }\end{array}$ & 8 & 888.9 & 9 & $409 \cdot 1$ & 22 & $628 \cdot 6$ & 11 & $846 \cdot 1$ & 10 & $476 \cdot 2$ & 16 & $666 \cdot 7$ \\
\hline $\begin{array}{l}\text { normal } \\
\text { Ventricular } \\
\text { extrasystoles } \\
\geqslant 10 \% \text { of all } \\
\text { recorded } \\
\text { complexes }\end{array}$ & 64 & $606 \cdot 2$ & 78 & $705 \cdot 6$ & 104 & $656 \cdot 2$ & 61 & $681 \cdot 3$ & 70 & $719 \cdot 7$ & 107 & $681 \cdot 7$ \\
\hline
\end{tabular}

${ }_{p}<0.1$ and ${ }^{\star \star} p<0.01$ for comparison of rates in actively treated group against placebo.

None of the comparisons of rates in one actively treated group with the other is significant even at the $p<0 \cdot 1$ level. 
Table 11 Incidence of electrocardiographic (ECG) abnormalities by smoking habit (rates per 1000 person-years)

\begin{tabular}{|c|c|c|c|c|c|c|c|c|c|c|c|c|}
\hline \multirow[b]{3}{*}{ ECG abnormality } & \multicolumn{6}{|c|}{ Men } & \multicolumn{6}{|c|}{ Women } \\
\hline & \multicolumn{2}{|c|}{ Bendrofluazide } & \multicolumn{2}{|c|}{ Propranolol } & \multicolumn{2}{|c|}{ Placebo } & \multicolumn{2}{|c|}{ Bendrofluazide } & \multicolumn{2}{|c|}{ Propranolol } & \multicolumn{2}{|c|}{ Placebo } \\
\hline & No & Rate & No & Rate & No & Rate & No & Rate & No & Rate & No & Rate \\
\hline \multicolumn{13}{|l|}{$\begin{array}{l}\text { Major Q/QS } \\
\text { abnormality }\end{array}$} \\
\hline $\begin{array}{c}\text { S } \\
\text { NS } \\
\text { Minor Q/QS } \\
\text { abnormality }\end{array}$ & $\begin{array}{l}29 \\
79\end{array}$ & $\begin{array}{l}12 \cdot 1 \\
13 \cdot 7\end{array}$ & $\begin{array}{l}25 \\
58\end{array}$ & $\begin{array}{r}10 \cdot 6 \\
9.4\end{array}$ & $\begin{array}{r}54 \\
115\end{array}$ & $\begin{array}{r}11 \cdot 2 \\
9 \cdot 6\end{array}$ & $\begin{array}{l}33 \\
72\end{array}$ & $\begin{array}{l}16 \cdot 8 \\
12 \cdot 4\end{array}$ & $\begin{array}{l}14 \\
64\end{array}$ & $\begin{array}{c}7 \cdot 1^{\circ} \\
10 \cdot 7^{\circ}\end{array}$ & $\begin{array}{r}49 \\
140\end{array}$ & $\begin{array}{l}12 \cdot 3 \\
12 \cdot 0\end{array}$ \\
\hline $\begin{array}{l}\text { S } \\
\text { NS } \\
\text { Tall } \mathbf{R}\end{array}$ & $\begin{array}{l}20 \\
59\end{array}$ & $\begin{array}{c}8.9 \\
11 \cdot 0^{\circ}\end{array}$ & $\begin{array}{l}16 \\
43\end{array}$ & $\begin{array}{l}7 \cdot 0 \\
7 \cdot 3\end{array}$ & $\begin{array}{l}42 \\
93\end{array}$ & $\begin{array}{l}9 \cdot 3 \\
8 \cdot 1\end{array}$ & $\begin{array}{l}18 \\
55\end{array}$ & $\begin{array}{r}9 \cdot 5 \\
10 \cdot 1\end{array}$ & $\begin{array}{l}16 \\
41\end{array}$ & $\begin{array}{l}8 \cdot 5 \\
7 \cdot 2\end{array}$ & $\begin{array}{r}45 \\
102\end{array}$ & $\begin{array}{r}12 \cdot 1 \\
9 \cdot 4\end{array}$ \\
\hline $\begin{array}{l}\text { waves } \\
\text { S } \\
\text { NS } \\
\text { ST-T } \\
\text { abnormalities }\end{array}$ & $\begin{array}{l}33 \\
80\end{array}$ & $\begin{array}{l}13 \cdot 8^{\star \star} \\
14 \cdot 6^{\star \star \star}\end{array}$ & $\begin{array}{r}38 \\
107\end{array}$ & $\begin{array}{l}16 \cdot 5^{\circ} \\
19 \cdot 1^{\circ}\end{array}$ & $\begin{array}{l}108 \\
257\end{array}$ & $\begin{array}{l}23 \cdot 4 \\
23 \cdot 1\end{array}$ & $\begin{array}{l}13 \\
58\end{array}$ & $\begin{array}{c}6 \cdot 6^{\star \star} \\
10 \cdot 3^{\star \star \star}\end{array}$ & $\begin{array}{l}22 \\
99\end{array}$ & $\begin{array}{l}11 \cdot 3 \\
17 \cdot 1\end{array}$ & $\begin{array}{r}67 \\
214\end{array}$ & $\begin{array}{l}17 \cdot 2 \\
19 \cdot 4\end{array}$ \\
\hline$\underset{\text { Strain }}{\text { NS }}$ & $\begin{array}{l}30 \\
49\end{array}$ & $\begin{array}{r}12 \cdot 2 \\
8 \cdot 3\end{array}$ & $\begin{array}{l}33 \\
29\end{array}$ & $\begin{array}{r}13 \cdot 8+t \dagger \\
4 \cdot 6 \star \star \star\end{array}$ & $\begin{array}{r}64 \\
128\end{array}$ & $\begin{array}{l}13 \cdot 6 \\
10 \cdot 4\end{array}$ & $\begin{array}{r}30 \\
115\end{array}$ & $\begin{array}{l}15 \cdot 3 \\
20 \cdot 4^{\star \star \star}\end{array}$ & $\begin{array}{l}28 \\
63\end{array}$ & $\begin{array}{l}14 \cdot 3 \\
10 \cdot 6\end{array}$ & $\begin{array}{r}55 \\
116\end{array}$ & $\begin{array}{c}13.7 \dagger \\
9 \cdot 8\end{array}$ \\
\hline $\begin{array}{l}\text { S } \\
\text { NS } \\
\text { T wave inverted, } \\
\text { ST segment } \\
\text { normal }\end{array}$ & $\begin{array}{r}5 \\
11\end{array}$ & $\begin{array}{l}2 \cdot 0 \\
1 \cdot 8\end{array}$ & $\begin{array}{r}5 \\
11\end{array}$ & $\begin{array}{l}2 \cdot 0 \\
1 \cdot 7\end{array}$ & $\begin{array}{l}15 \\
30\end{array}$ & $\begin{array}{l}3 \cdot 1 \\
2 \cdot 4\end{array}$ & $\begin{array}{l}1 \\
7\end{array}$ & $\begin{array}{l}0.5 \\
1 \cdot 2^{\circ}\end{array}$ & $\begin{array}{r}3 \\
12\end{array}$ & $\begin{array}{l}1.5 \\
1.9\end{array}$ & $\begin{array}{r}9 \\
32\end{array}$ & $\begin{array}{l}2 \cdot 2 \\
2 \cdot 6\end{array}$ \\
\hline $\begin{array}{l}\text { S } \\
\text { NS } \\
\text { T wave flat or } \\
\text { minimally } \\
\text { inverted, } \\
\text { ST segment } \\
\text { normal }\end{array}$ & $\begin{array}{l}11 \\
21\end{array}$ & $\begin{array}{l}4 \cdot 5^{\circ} \\
3 \cdot 7^{\circ}\end{array}$ & $\begin{array}{l}23 \\
35\end{array}$ & $\begin{array}{l}9 \cdot 9 \\
5 \cdot 7\end{array}$ & $\begin{array}{l}39 \\
69\end{array}$ & $\begin{array}{l}8 \cdot 3 \\
5 \cdot 9\end{array}$ & $\begin{array}{l}12 \\
34\end{array}$ & $\begin{array}{l}6 \cdot 4 \\
6 \cdot 4^{\star}\end{array}$ & $\begin{array}{l}21 \\
59\end{array}$ & $\begin{array}{l}11 \cdot 3^{\star} \\
10 \cdot 2^{\star \star \star}\end{array}$ & $\begin{array}{l}19 \\
40\end{array}$ & $\begin{array}{l}5 \cdot 0 \\
3.6\end{array}$ \\
\hline $\begin{array}{c}\text { S } \\
\text { NS }\end{array}$ & $\begin{array}{l}39 \\
89\end{array}$ & $\begin{array}{l}18 \cdot 4^{\star \star} \\
17 \cdot 6^{\circ}\end{array}$ & $\begin{array}{l}47 \\
99\end{array}$ & $\begin{array}{l}23 \cdot 9 \\
18 \cdot 2^{\circ}\end{array}$ & $\begin{array}{l}125 \\
237\end{array}$ & $\begin{array}{l}31 \cdot 3+\dagger \\
22 \cdot 5\end{array}$ & $\begin{array}{r}44 \\
136\end{array}$ & $\begin{array}{l}28 \cdot 2 \\
31 \cdot 6^{\star}\end{array}$ & $\begin{array}{r}32 \\
136\end{array}$ & $\begin{array}{l}21 \cdot 0 \\
28 \cdot 1\end{array}$ & $\begin{array}{r}92 \\
238\end{array}$ & $\begin{array}{l}27 \cdot 3 \\
24 \cdot 4\end{array}$ \\
\hline NS & $\begin{array}{l}17 \\
40\end{array}$ & $\begin{array}{l}6 \cdot 7 \\
6 \cdot 7\end{array}$ & $\begin{array}{l}15 \\
25\end{array}$ & $\begin{array}{l}6 \cdot 0 \\
4 \cdot 0^{\circ}\end{array}$ & $\begin{array}{l}33 \\
77\end{array}$ & $\begin{array}{l}6 \cdot 7 \\
6 \cdot 2\end{array}$ & $\begin{array}{l}15 \\
34\end{array}$ & $\begin{array}{l}7 \cdot 3 \\
5 \cdot 8\end{array}$ & $\begin{array}{l}12 \\
27\end{array}$ & $\begin{array}{l}6 \cdot 1 \\
4 \cdot 4\end{array}$ & $\begin{array}{l}25 \\
55\end{array}$ & $\begin{array}{l}6 \cdot 3 \\
4 \cdot 6\end{array}$ \\
\hline
\end{tabular}

${ }^{0} p<0.1 ;{ }^{\star} p<0.05 ;{ }^{\star \star} p<0.01 ;{ }^{\star \star \star} p<0.001 ;$ for comparison of rates on either active drug with rates on placebo. tp $<0.05$; †tp $<0.01$; ††p $<0.001$; for comparison of rates in smokers with rates in non-smokers.

$\mathrm{S}$, smokers; NS, non-smokers.

inconclusive. An analysis of the interaction between the type of treatment and smoking in determining coronary events did not give a statistically significant result $(p=0 \cdot 11)$ and although the putative effect was proportionally large, with about one third of events saved, the difference between event rates in the propranolol and placebo groups was only just statistically significant $(p=0.04)$.

The absence of a convincing dose-response relation in the present data between the number of cigarettes smoked daily and the percentage reduction in the coronary event rate in men on propranolol also serves to reduce the credibility of the postulated effect, and we now reiterate and re-emphasise the caution expressed in our first paper ${ }^{1}$ about the interpretation of post hoc subgroup findings. The theory, however, receives some support from the independent finding in the International Prospective
Primary Prevention Study in Hypertension of a similar effect in a group treated with oxprenolol. ${ }^{6} \mathrm{It}$ is 의 known that the antihypertensive action of propranolol differs between smokers and non-smokers, and other drug effects might be similarly modified by smoking. ${ }^{10}$

Active treatment had a beneficial effect on the $\tilde{N}$ electrocardiographic changes thought to be caused $\mathrm{W}$ by cardiac hypertrophy, both in reducing their incidence (in accord with other published work $^{11}$ ) $Q$ and in increasing the proportion reverting to normal. The factors modulating the reversal of such electrocardiographic changes are clearly complex, ${ }^{1213}$ and are not restricted to changes in blood pressure, for in our results as in other published work ${ }^{14}$ the comparative efficacy of the two drugs in this respect differs from that of their antihypertensive action. ${ }^{1}$

The decreased occurrence of repolarisation abnor- 
Table 12 Reversion of electrocardiographic (ECG) abnormalities by smoking habit (rates per thousand person-years)

\begin{tabular}{|c|c|c|c|c|c|c|c|c|c|c|c|c|}
\hline \multirow[b]{3}{*}{ ECG abnormality } & \multicolumn{6}{|c|}{ Men } & \multicolumn{6}{|c|}{ Women } \\
\hline & \multicolumn{2}{|c|}{ Bendrofluazide } & \multicolumn{2}{|c|}{ Propranolol } & \multicolumn{2}{|c|}{ Placebo } & \multicolumn{2}{|c|}{ Bendrofluazide } & \multicolumn{2}{|c|}{ Propranolol } & \multicolumn{2}{|c|}{ Placebo } \\
\hline & No & Rate & No & Rate & No & Rate & No & Rate & No & Rate & No & Rate \\
\hline \multicolumn{13}{|l|}{$\begin{array}{l}\text { Major Q/QS } \\
\text { abnormality }\end{array}$} \\
\hline $\begin{array}{l}\text { S } \\
\text { NS } \\
\text { Minor Q/QS } \\
\text { abnormality }\end{array}$ & $\begin{array}{r}6 \\
12\end{array}$ & $\begin{array}{l}313 \cdot 7 \\
545 \cdot 2\end{array}$ & $\begin{array}{r}7 \\
12\end{array}$ & $\begin{array}{l}437.5 \\
461.5\end{array}$ & $\begin{array}{l}14 \\
33\end{array}$ & $\begin{array}{l}359.0 \\
393.9\end{array}$ & $\begin{array}{r}7 \\
20\end{array}$ & $\begin{array}{l}700 \cdot 0 \\
623 \cdot 1\end{array}$ & $\begin{array}{r}7 \\
24\end{array}$ & $\begin{array}{l}636 \cdot 4 \\
470 \cdot 6\end{array}$ & $\begin{array}{l}12 \\
34\end{array}$ & $\begin{array}{l}625 \cdot 2 \\
629 \cdot 6\end{array}$ \\
\hline $\begin{array}{l}\text { S } \\
\text { NS } \\
\text { Tall } R \\
\text { waves }\end{array}$ & $\begin{array}{l}10 \\
26\end{array}$ & $\begin{array}{l}666 \cdot 7 \\
722 \cdot 2\end{array}$ & $\begin{array}{r}7 \\
19\end{array}$ & $\begin{array}{l}500 \cdot 0 \\
387 \cdot 8\end{array}$ & $\begin{array}{l}19 \\
44\end{array}$ & $\begin{array}{l}638 \cdot 5 \\
569 \cdot 4\end{array}$ & $\begin{array}{r}9 \\
20\end{array}$ & $\begin{array}{l}486 \cdot 0 \\
526 \cdot 3\end{array}$ & $\begin{array}{r}9 \\
17\end{array}$ & $\begin{array}{l}428 \cdot 6 \\
586 \cdot 2\end{array}$ & $\begin{array}{l}16 \\
46\end{array}$ & $\begin{array}{l}468 \cdot 7 \\
676 \cdot 5\end{array}$ \\
\hline $\begin{array}{l}\text { S } \\
\text { NS } \\
\text { ST-T } \\
\text { abnormalities }\end{array}$ & $\begin{array}{l}29 \\
65\end{array}$ & $\begin{array}{l}513 \cdot 8 \\
410.7\end{array}$ & $\begin{array}{l}26 \\
85\end{array}$ & $\begin{array}{l}587 \cdot 3 \\
491.7\end{array}$ & $\begin{array}{r}53 \\
142\end{array}$ & $\begin{array}{l}405 \cdot 3 \\
347 \cdot 0\end{array}$ & $\begin{array}{l}10 \\
52\end{array}$ & $\begin{array}{l}434 \cdot 8 \\
424 \cdot 6\end{array}$ & $\begin{array}{l}12 \\
50\end{array}$ & $\begin{array}{l}428 \cdot 6 \\
347 \cdot 2\end{array}$ & $\begin{array}{r}18 \\
118\end{array}$ & $\begin{array}{l}304 \cdot 2 \\
352 \cdot 1\end{array}$ \\
\hline $\begin{array}{l}\text { S } \\
\text { Strain }\end{array}$ & $\begin{array}{r}4 \\
19\end{array}$ & $\begin{array}{l}444 \cdot 4 \\
450 \cdot 4\end{array}$ & $\begin{array}{r}4 \\
11\end{array}$ & $\begin{array}{l}571 \cdot 4 \\
289 \cdot 5\end{array}$ & $\begin{array}{r}9 \\
24\end{array}$ & $\begin{array}{l}236 \cdot 8 \\
395 \cdot 7\end{array}$ & $\begin{array}{l}12 \\
24\end{array}$ & $\begin{array}{l}463 \cdot 8 \\
421 \cdot 0\end{array}$ & $\begin{array}{r}4 \\
17\end{array}$ & $\begin{array}{l}333 \cdot 3 \\
485 \cdot 3\end{array}$ & $\begin{array}{l}12 \\
43\end{array}$ & $\begin{array}{l}600 \cdot 0 \\
412 \cdot 9\end{array}$ \\
\hline $\begin{array}{l}\text { S } \\
\text { NS } \\
\text { T wave inverted, } \\
\text { ST segment } \\
\text { normal }\end{array}$ & $\begin{array}{l}1 \\
6\end{array}$ & $\begin{array}{r}1000 \cdot 0 \\
750 \cdot 0\end{array}$ & $\begin{array}{l}1 \\
4\end{array}$ & $\begin{array}{r}1000 \cdot 0 \\
400 \cdot 0\end{array}$ & $\begin{array}{l}5 \\
8\end{array}$ & $\begin{array}{l}833 \cdot 3 \\
666 \cdot 7\end{array}$ & $\begin{array}{l}2 \\
3\end{array}$ & $\begin{array}{l}666 \cdot 7 \\
750 \cdot 0\end{array}$ & $\begin{array}{l}1 \\
4\end{array}$ & $\begin{array}{r}1000 \cdot 0 \\
571 \cdot 4\end{array}$ & $\begin{array}{r}0 \\
13\end{array}$ & $\begin{array}{r}0.0 \\
565 \cdot 2\end{array}$ \\
\hline $\begin{array}{l}\text { S } \\
\text { NS } \\
\text { T wave flat or } \\
\text { minimally } \\
\text { inverted, } \\
\text { ST segment } \\
\text { normal }\end{array}$ & $\begin{array}{l}2 \\
5\end{array}$ & $\begin{array}{r}1000 \cdot 0 \\
274 \cdot 8\end{array}$ & $\begin{array}{l}4 \\
5\end{array}$ & $\begin{array}{l}571 \cdot 4 \\
333.3\end{array}$ & $\begin{array}{r}4 \\
18\end{array}$ & $\begin{array}{r}1000 \cdot 0 \\
580 \cdot 6\end{array}$ & $\begin{array}{l}4 \\
7\end{array}$ & $\begin{array}{r}1000 \cdot 0 \\
777 \cdot 8\end{array}$ & $\begin{array}{l}3 \\
7\end{array}$ & $\begin{array}{l}750 \cdot 0 \\
411 \cdot 8\end{array}$ & $\begin{array}{r}4 \\
12\end{array}$ & $\begin{array}{l}571 \cdot 4 \\
705 \cdot 9\end{array}$ \\
\hline $\begin{array}{l}\text { S } \\
\text { NS } \\
\text { Ventricular } \\
\text { extrasystoles } \\
\geqslant 10 \% \text { of } \\
\text { recorded } \\
\text { complexes }\end{array}$ & $\begin{array}{l}18 \\
46\end{array}$ & $\begin{array}{l}476 \cdot 5 \\
682 \cdot 6\end{array}$ & $\begin{array}{l}24 \\
54\end{array}$ & $\begin{array}{l}705 \cdot 9 \\
709 \cdot 5\end{array}$ & $\begin{array}{l}38 \\
66\end{array}$ & $\begin{array}{l}614 \cdot 7 \\
707 \cdot 0\end{array}$ & $\begin{array}{l}20 \\
41\end{array}$ & $\begin{array}{l}833 \cdot 3 \\
624 \cdot 7\end{array}$ & $\begin{array}{l}25 \\
45\end{array}$ & $\begin{array}{l}660 \cdot 4 \\
789 \cdot 5\end{array}$ & $\begin{array}{l}25 \\
82\end{array}$ & $\begin{array}{l}714 \cdot 3 \\
664 \cdot 9\end{array}$ \\
\hline NS & $\begin{array}{l}1 \\
6\end{array}$ & $\begin{array}{r}1000 \cdot 0 \\
545 \cdot 4\end{array}$ & $\begin{array}{l}2 \\
7\end{array}$ & $\begin{array}{r}1000 \cdot 0 \\
875 \cdot 0\end{array}$ & $\begin{array}{r}4 \\
13\end{array}$ & $\begin{array}{l}666 \cdot 7 \\
812 \cdot 5\end{array}$ & $\begin{array}{l}6 \\
5\end{array}$ & $\begin{array}{l}857 \cdot 1 \\
500 \cdot 0\end{array}$ & $\begin{array}{l}5 \\
5\end{array}$ & $\begin{array}{l}714 \cdot 3 \\
500 \cdot 0\end{array}$ & $\begin{array}{r}7 \\
15\end{array}$ & $\begin{array}{l}538 \cdot 5 \\
833 \cdot 3\end{array}$ \\
\hline
\end{tabular}

S, smokers; NS, non-smokers.

No differences between rates in drug groups compared with the placebo group, or in the active drug groups compared with one another, were significant even at the $p<0.1$ level.

malities in men on bendrofluazide shown here has been reported before ${ }^{11}$ but (to our knowledge) the difference between the sexes, with an increased rate in women, has not. The reason for this sex difference is unclear. Repolarisation abnormalities are associated with reduced concentrations of serum potas- sium, but the potassium-lowering effect of bendrofluazide was similar in men and women. ${ }^{15}$

Our data do not unequivocally confirm the suggestion made in the report on the MRFIT study that thiazide diuretics might increase the rate of coronary heart disease mortality in men with baseline resting

Table 13 Incidence of ventricular extrasystoles ${ }^{\star}$ by year of follow up

\begin{tabular}{|c|c|c|c|c|c|c|c|c|c|c|c|c|}
\hline \multirow[b]{2}{*}{ Time in trial } & \multicolumn{6}{|c|}{ Men } & \multicolumn{6}{|c|}{ Women } \\
\hline & \multicolumn{2}{|c|}{$\begin{array}{l}\text { Bendrofluazide } \\
\text { No Rate }\end{array}$} & \multicolumn{2}{|c|}{$\begin{array}{l}\text { Propranolol } \\
\text { No Rate }\end{array}$} & \multicolumn{2}{|c|}{ Placebo } & \multicolumn{2}{|c|}{$\begin{array}{l}\text { Bendrofluazide } \\
\text { No Rate }\end{array}$} & \multicolumn{2}{|c|}{$\begin{array}{l}\text { Propranolol } \\
\text { No Rate }\end{array}$} & $\begin{array}{l}\text { Placebo } \\
\text { No }\end{array}$ & Rate \\
\hline $\begin{array}{l}\text { Entry to } 1 \text { year } \\
1-2 \text { years } \\
2-3 \text { years } \\
3-4 \text { years } \\
4-5 \text { years }\end{array}$ & $\begin{array}{r}19 \\
12 \\
14 \\
10 \\
2\end{array}$ & $\begin{array}{l}9 \cdot 3 \\
6 \cdot 2 \\
7 \cdot 7 \\
5 \cdot 9 \\
1 \cdot 7\end{array}$ & $\begin{array}{r}10 \\
8 \\
7 \\
5 \\
10\end{array}$ & $\begin{array}{l}4 \cdot 8 \\
4 \cdot 0 \\
3 \cdot 7 \\
2 \cdot 9 \\
8 \cdot 0\end{array}$ & $\begin{array}{l}22 \\
23 \\
28 \\
25 \\
12\end{array}$ & $\begin{array}{l}5 \cdot 3 \\
5 \cdot 9 \\
7 \cdot 5 \\
7 \cdot 4 \\
5 \cdot 0\end{array}$ & $\begin{array}{r}13 \\
14 \\
8 \\
8 \\
6\end{array}$ & $\begin{array}{l}\mathbf{6} \cdot 9 \\
\mathbf{7} \cdot 9 \\
\mathbf{4} \cdot 7 \\
\mathbf{5} \cdot 0 \\
\mathbf{5} \cdot 0\end{array}$ & $\begin{array}{r}10 \\
9 \\
6 \\
7 \\
7\end{array}$ & $\begin{array}{l}5 \cdot 2 \\
4 \cdot 9 \\
3 \cdot 4 \\
4 \cdot 3 \\
5 \cdot 8\end{array}$ & $\begin{array}{l}13 \\
22 \\
12 \\
19 \\
14\end{array}$ & $\begin{array}{l}3 \cdot 4 \\
6 \cdot 1 \\
3 \cdot 5 \\
6 \cdot 0 \\
6 \cdot 0\end{array}$ \\
\hline
\end{tabular}

*Totalling $\geqslant 10 \%$ of all recorded complexes (Minnesota code $8_{1}(V)$ ).

$\star \star$ Rate per 1000 person-years. 
Table 14 Relation between electrocardiographic (ECG) abnormalities and the occurrence of clinically evident coronary events $\mathrm{C}$

\begin{tabular}{|c|c|c|c|c|c|c|c|c|c|c|c|c|}
\hline \multirow[b]{3}{*}{ ECG abnormality } & \multicolumn{6}{|c|}{ Men } & \multicolumn{6}{|c|}{ Women } \\
\hline & \multicolumn{2}{|c|}{ Bendrofluazide } & \multicolumn{2}{|c|}{ Propranolol } & \multicolumn{2}{|c|}{ Placebo } & \multicolumn{2}{|c|}{ Bendrofluazide } & \multicolumn{2}{|c|}{ Propranolol } & \multicolumn{2}{|c|}{ Placebo } \\
\hline & No & Rate & No & Rate & No & Rate & No & Rate & No & Rate & No & Rate \\
\hline
\end{tabular}

Major Q/QS

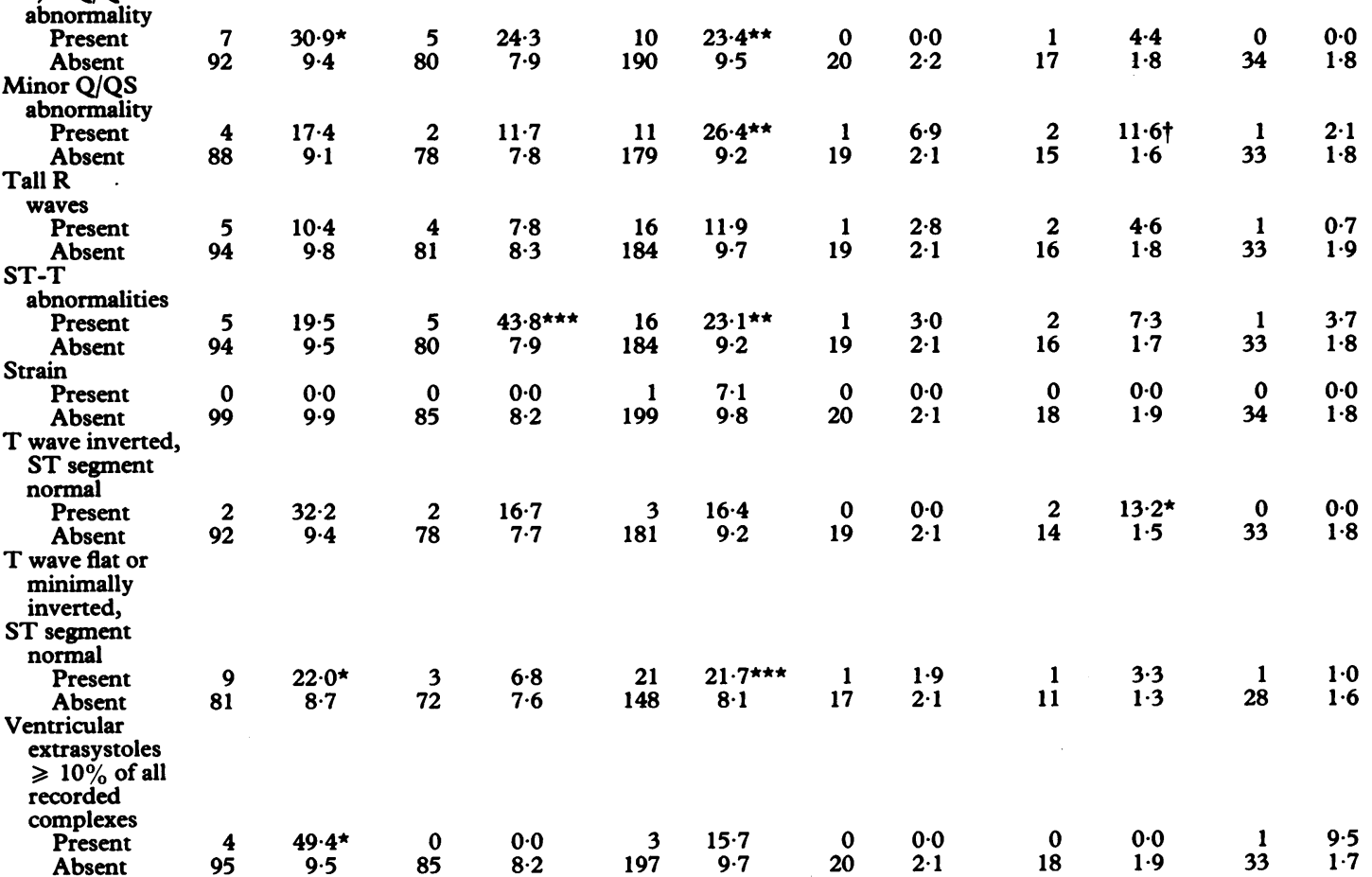

Major Q/QS

abnormality

Present
Absent

Minor Q/QS

abnormality

Present

$\begin{array}{llll}95 & 9.5 & 85 & 8 \cdot 2\end{array}$

Absent

$8^{\circ} \quad 34 \cdot 2^{\star \star \star} \quad 4^{\circ} \quad 19 \cdot 4^{\star \star}$

Fatal coronary events

Tall R

waves

Present

Absent

$$
40
$$

$\begin{array}{rrrr}2 & 8.9 & 2 & 11.7 \\ 40 & 4.1 & 32 & 3.2\end{array}$

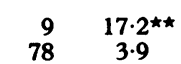

$\begin{array}{ll}0 & 0.0 \\ 9 & 1.0\end{array}$

$\begin{array}{rrrr}0 & 0.0 & 0 & 0.0 \\ 9 & 1.0 & 10 & 0.5\end{array}$

ST-T

abnormalities

abnormalities
Present
Absent
Strain
Present
Absent
T wave inverted,
ST segment
normal

normal

Present

$$
\begin{array}{rr}
1 & 1 \cdot 9 \\
49 & 5 \cdot 1
\end{array}
$$

$\begin{array}{rr}2 & 3.4 \\ 36 & 3.7\end{array}$

$\begin{array}{cc}5 & 13 \cdot 0^{\star} \\ 73 & 3 \cdot 7\end{array}$

$\begin{array}{ll}0 & 0.0 \\ 9 & 1.0\end{array}$

$\begin{array}{llll}1 & 6.1 & 1 & 2.1 \\ 8 & 0.9 & 9 & 0.5\end{array}$

$\begin{array}{rr}4 & 12 \cdot 7 \\ 46 & 4 \cdot 7\end{array}$

$\begin{array}{rr}0 & 0 \cdot 0 \\ 50 & 5 \cdot 0\end{array}$

5
33

$43 \cdot 8^{\star \star \star}$

$\begin{array}{rr}8 & 5 \cdot 8 \\ 79 & 4 \cdot 2\end{array}$

$\mathbf{1}$

$2 \cdot 8$
$0 \cdot 9$

$\begin{array}{llll}1 & 2.7 & 1 & 0.7 \\ 8 & 0.9 & 9 & 0.5\end{array}$

Absent

4

$\begin{array}{rrrr}1 & 22 \cdot 5 & 1 & 10 \cdot 2 \\ 45 & 4 \cdot 6 & 32 & 3 \cdot 2\end{array}$

3.2
0.0
3.7


$10 \cdot 2$
3.2

$13 \quad 19 \cdot 1 \star \star \star$

$\begin{array}{ll}74 & 3.7\end{array}$

0
9

$\begin{array}{rr}1 & 7 \cdot 1 \\ 86 & 4 \cdot 2\end{array}$

$\begin{array}{cc}3 & 11 \cdot 6 \dagger \\ 71 & 3.6\end{array}$

$\begin{array}{lll}11.6 \dagger & 0 & 0.0 \\ 3.6 & 9 & 1.0\end{array}$

0.0
$1 \cdot 0$

0.0
1.0
$\begin{array}{llll}0 & 0.0 & 1 & 3.7 \\ 9 & 0.9 & 9 & 0.5\end{array}$
$\begin{array}{rrrr}0 & 0.0 & 0 & 0.0 \\ 9 & 0.9 & 10 & 0.5\end{array}$




\begin{tabular}{|c|c|c|c|c|c|c|c|c|c|c|c|c|}
\hline \multirow[b]{3}{*}{ ECG abnormality } & \multicolumn{6}{|c|}{ Men } & \multicolumn{6}{|c|}{ Women } \\
\hline & \multicolumn{2}{|c|}{ Bendrofluazide } & \multicolumn{2}{|c|}{ Propranolol } & \multicolumn{2}{|c|}{ Placebo } & \multicolumn{2}{|c|}{ Bendrofluazide } & \multicolumn{2}{|c|}{ Propranolol } & \multicolumn{2}{|c|}{ Placebo } \\
\hline & No & Rate & No & Rate & No & Rate & No & Rate & No & Rate & No & Rate \\
\hline $\begin{array}{l}\text { T wave flat or } \\
\text { minimally } \\
\text { inverted, } \\
\text { ST segment } \\
\text { normal }\end{array}$ & & & & & & & & & & & & \\
\hline $\begin{array}{l}\text { Present } \\
\text { Absent } \\
\text { Ventricular } \\
\text { extrasystoles } \\
\geqslant 10 \% \text { of } \\
\text { recorded } \\
\text { complexes }\end{array}$ & $\begin{array}{r}3 \\
39\end{array}$ & $\begin{array}{l}6 \cdot 5 \\
4 \cdot 2\end{array}$ & $\begin{array}{r}3 \\
26\end{array}$ & $\begin{array}{l}6 \cdot 8 \\
2 \cdot 7\end{array}$ & $\begin{array}{l}10 \\
54\end{array}$ & $\begin{array}{l}9 \cdot 4^{\star \star} \\
2 \cdot 9\end{array}$ & $\begin{array}{l}0 \\
9\end{array}$ & $\begin{array}{l}0 \cdot 0 \\
1 \cdot 1\end{array}$ & $\begin{array}{l}1 \\
7\end{array}$ & $\begin{array}{l}3.3 \\
0.8\end{array}$ & $\begin{array}{l}\mathbf{0} \\
\mathbf{7}\end{array}$ & $\begin{array}{l}0.0 \\
0.4\end{array}$ \\
\hline $\begin{array}{l}\text { Present } \\
\text { Absent }\end{array}$ & $\begin{array}{r}5 \\
45\end{array}$ & $\begin{array}{c}56 \cdot 9 \star \star \star \\
4.5\end{array}$ & $\begin{array}{r}0 \\
38\end{array}$ & $\begin{array}{l}0.0 \\
3.7\end{array}$ & $\begin{array}{r}4 \\
83\end{array}$ & $\begin{array}{c}23 \cdot 2^{\star \star} \\
4 \cdot 1\end{array}$ & $\begin{array}{l}0 \\
9\end{array}$ & $\begin{array}{l}0.0 \\
1.0\end{array}$ & $\begin{array}{l}0 \\
9\end{array}$ & $\begin{array}{l}0.0 \\
0.9\end{array}$ & $\begin{array}{r}0 \\
10\end{array}$ & $\begin{array}{l}0.0 \\
0.5\end{array}$ \\
\hline
\end{tabular}

${ }^{O}$ The number of fatal events shown in any one line may appear to exceed the number of fatal and non-fatal events combined if the ECG has changed between a non-fatal and a fatal event.

tp $<0.1 ;{ }^{\star} p<0.05 ;{ }^{\star \star} p<0.01 ;{ }^{\star \star \star} p<0.001$; for comparison of rate with ECG abnormality present against rate in group without abnormality.

electrocardiographic abnormalities. ${ }^{4}$ The MRFIT results may have been distorted by the anomalous finding in the control group of lower mortality from coronary heart disease in men with abnormal electrocardiograms than in those with normal electrocardiograms. In the present results it was clear that the presence of major electrocardiographic abnormalities was associated with an increased likelihood of having a clinical event, but there was no evidence that this relation, whether for all events or for fatal events only, was strengthened by bendrofluazide treatment.

There are none the less certain aspects of our results that need careful assessment with respect to the postulated adverse effect associated with bendrofluazide treatment. These include the finding, noted early in the study, of an excess of sudden deaths in men in the thiazide group compared with those on placebo. This excess, small and not statistically significant, did not justify changing the protocol or stopping the trial. Two substudies were then set up to try to detect adverse effects possibly associated with the rather high (10 mg daily) dose of bendrofluazide. In one, the antihypertensive efficacy of, and adverse reactions to, two doses of bendrofluazide were compared. ${ }^{16}$ In the second, the relation between thiazide treatment and ventricular extrasystoles was examined, and showed an increase in the occurrence of ventricular extrasystoles in the first year of bendrofluazide treatment which was not maintained subsequently. ${ }^{17}$

The sudden death rate was slightly, though not statistically significantly, increased on bendrofluazide compared with placebo. There was a slight increase in major $\mathrm{Q} / \mathrm{QS}$ abnormalities in men on bendrofluazide ( $p=0.03$ compared with the placebo group). The rates of coronary events on bendrofluazide in the presence of major $\mathrm{Q} / \mathrm{QS}$ abnormalities or a high frequency of ventricular extrasystoles were increased, though not statistically significantly so. Taken singly, none of these findings has great weight. When all are considered together, although our data do not definitely support the suspicion raised in the MRFIT report, neither do they refute it.

As well as information about clinical events, this study gave considerable information on electrocardiographic changes. The frequency and reversion of these abnormalities were defined as the first recorded change in an individual, whatever alterations occurred subsequently - a simple way of handling the data but one which will to some extent have inflated the figures. Other work, however, describes higher rates for reversion even of $Q$ waves ${ }^{18}{ }^{19}$ so our approach may not have greatly exaggerated the results, and is free of apparent bias. Each treatment used in the trial may, however, in different ways, have altered the relation of electrocardiographic findings to clinical disease, and made interpretation difficult. Taken as a whole, the most interesting aspect of the electrocardiographic findings is the difference between the results for $\mathrm{Q} / \mathrm{QS}$ changes in "silent" infarctions, and those for clinically evident coronary events. The incidence of the former differed little between men and women or between smokers and non-smokers, contrasting strongly with the results for clinical episodes, and the possible protective effect of propranolol against coronary events in non-smokers was not evident against the electrocar- 
diographic changes. Factors other than myocardial ischaemia which predispose to the development of clinical manifestations of infarction may be more common in men than in women and more in smokers than in non-smokers, and the putative protective effect of propranolol could be exerted against one of these factors.

These results are tantalising. They include two suggestions of benefit associated with propranolol and of hazard associated with bendrofluazide which, if substantiated, would be of considerable importance but which even a study of this size fails conclusively to demonstrate. These findings alone are difficult to use as a basis for decisions about the choice of drug treatment for mild hypertension and should be considered together with those for the effects of treatment on the stroke rate ${ }^{1}$ which are shortly to be presented in more detail with fuller information for subgroup analyses.

The following were members of the working party: Professor Sir Stanley Peart (chairman), Mrs GR Barnes (until 1983), Mr PMG Broughton, Mr PJ Brennan, Professor Sir Colin Dollery, Dr KG Green (until 1983), Dr MF Hudson, Dr AF Lever, Dr TW Meade, Dr WE Miall (secretary until 1983), Mr K Rennolls, Professor GA Rose, the late Dr BC Smith (until 1980), Dr P Wilding (until 1977), and Dr G Greenberg (secretary).

We thank the general practitioners and nurses belonging to the research framework: Professor HD Tunstall Pedoe for assessing all terminating events; Professor D Julian and Professor AJ Camm for commenting on a draft version of this paper; Professor TP Whitehead and Mr PMG Broughton and the staff of the Wolfson Research Laboratories, Queen Elizabeth Medical Centre, Birmingham, for carrying out the biochemical analyses; Duncan Flockhart for tablets of bendrofluazide and placebo; Imperial Chemical Industries Ltd for financial support and for tablets of propranolol and placebo; CIBA laboratories for supplies of guanethidine; and Merck Sharp \& Dohme for a mobile screening unit, funds for its staffing, and supplies of methyldopa.

\section{References}

1 Medical Research Council Working Party. MRC trial of treatment of mild hypertension: principal results. $\mathrm{Br}$ Med J 1985;291:97-104.

2 Hypertension Detection and Follow-up Program Co-operative Group. Five-year findings of the hypertension detection and follow-up program. JAMA 1979;242:2562-77.

3 Australian National Blood Pressure Study Management
Committee. The Australian therapeutic trial in mild hypertension. Lancet 1980;i:1261-7.

4 Multiple Risk Factor Intervention Trial Research Group. Multiple risk factor intervention trial. JAMA 1982;248:1465-77.

5 Leren P. The hypertension-CHD dilemma. Acta Med $\overline{\bar{c}}$ Scand 1985;217:145-7.

6 The IPPPSH Collaborative Group. Cardiovascular risk $\unrhd$ and risk factors in a randomised trial of treatment $\stackrel{\omega}{\omega}$ based on the beta-blocker oxprenolol: the inter- $\vec{P}$ national prospective primary prevention study in hypertension (IPPPSH). J Hypertens 1985;3:379-92. $\vec{\omega}$

7 Prineas RJ, Crow RS, Blackburn H. The Minnesota code. Manual of electrocardiographic findings. Boston: John Wright, 1982.

8 World Health Organisation Regional Office for Europe. Myocardial infarction community registers. (Public $\omega$ Health in Europe No. 5.) Copenhagen: WHO, 1976.

9 Helgeland A. Treatment of mild hypertension: a fiveyear controlled drug trial. The Oslo study. Am J Med 1980;69:725-32.

10 Greenberg G, Thompson SG, Brennan PJ. The relationship between smoking and the response to $\widehat{\widehat{O}}$ treatment in the Medical Research Council's trial of anti-hypertensive treatment. Int $J$ Epidemiol 1987; $\vec{\oplus}$ 16:25-30.

11 Freis ED. ECG changes in the course of antihypertensive treatment. Am J Med 1983;75(suppl 3A):111-5.

12 Tarazi RC. Regression of LVH by medical treatment: present status and possible implications. Am J Med 1983;175(suppl 3A):80-6.

13 Sen S. Regression of cardiac hypertrophy: experimental animal model. Am J Med 1983;75(suppl 3A):87-93.

14 Samuelsson O, Berglund G, Elmfeldt D, Wilhelmsen L, Wiksbrand J. QRS amplitudes during antihyper- $\bar{Z}$ tensive treatment: a comparison between beta- $\overline{0}$

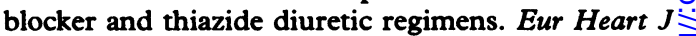
1986;7:254-61.

15 Medical Research Council working party on mild to moderate hypertension. Adverse reactions to $\bar{\sigma}$ bendrofluazide and propranolol for the treatment of 3 . mild hypertension. Lancet 1981 ;ii:539-43.

16 Medical Research Council working party on mild to moderate hypertension. Comparison of the antihypertensive efficacy and adverse reactions to two $工$ doses of bendrofluazide and hydrochlorothiazide, and $D$ the effect of potassium supplementation on the hypotensive action of bendrofluazide. $J$ Clin N Pharmacol 1987;27:271-7.

17 Medical Research Council working party on mild to $\mathcal{O}$ moderate hypertension. Ventricular extrasystoles $\mathbb{W}$ during thiazide treatment. $\mathrm{Br} M e d J$ 1983;287:0 1249-53.

18 Wasserman AG, Bren G, Ross AM, Richardson DW, Hutchinson RG, Rios JC. Prognostic implications of the diagnostic $Q$-wave after myocardial infarction. Circulation 1982;65:1451-5.

19 CDP Research Group. The Coronary Drug Project: design, methods and baseline results. Circulation $\bigcirc$ 1973;47(suppl 1): I II 1-150. 